\title{
Cancer Stem Cell for Tumor Therapy
}

\author{
Binjie Huang ${ }^{1,2} \mathbb{C}^{-}$, Xin Yan $^{1,2}$ and Yumin $\mathrm{Li}^{1,2, *}$ \\ 1 Department of General Surgery, Second Hospital of Lanzhou University, Lanzhou 730030, China; \\ huangbj20@lzu.edu.cn (B.H.); yanx20@lzu.edu.cn (X.Y.) \\ 2 Key Laboratory of the Digestive System Tumors of Gansu Province, Second Hospital of Lanzhou University, \\ Lanzhou 730030, China \\ * Correspondence: liym@lzu.edu.cn; Tel.: +86-138-9361-5421
}

check for updates

Citation: Huang, B.; Yan, X.; Li, Y. Cancer Stem Cell for Tumor Therapy. Cancers 2021, 13, 4814. https:// doi.org/10.3390/cancers13194814

Academic Editor: Sanjay Gupta

Received: 24 August 2021

Accepted: 23 September 2021

Published: 26 September 2021

Publisher's Note: MDPI stays neutral with regard to jurisdictional claims in published maps and institutional affiliations.

Copyright: (C) 2021 by the authors Licensee MDPI, Basel, Switzerland. This article is an open access article distributed under the terms and conditions of the Creative Commons Attribution (CC BY) license (https:// creativecommons.org/licenses/by/ $4.0 /)$.
Simple Summary: Although many methods have been applied in clinical treatment for tumors, they still always show a poor prognosis. Molecule targeted therapy has revolutionized tumor therapy, and a proper target must be found urgently. With a crucial role in tumor development, metastasis and recurrence, cancer stem cells have been found to be a feasible and potential target for tumor therapy. We list the unique biological characteristics of cancer stem cells and summarize the recent strategies to target cancer stem cells for tumor therapy, through which we hope to provide a comprehensive understanding of cancer stem cells and find a better combinational strategy to target cancer stem cells for tumor therapy.

Abstract: Tumors pose a significant threat to human health. Although many methods, such as operations, chemotherapy and radiotherapy, have been proposed to eliminate tumor cells, the results are unsatisfactory. Targeting therapy has shown potential due to its specificity and efficiency. Meanwhile, it has been revealed that cancer stem cells (CSCs) play a crucial role in the genesis, development, metastasis and recurrence of tumors. Thus, it is feasible to inhibit tumors and improve prognosis via targeting CSCs. In this review, we provide a comprehensive understanding of the biological characteristics of CSCs, including mitotic pattern, metabolic phenotype, therapeutic resistance and related mechanisms. Finally, we summarize CSCs targeted strategies, including targeting CSCs surface markers, targeting CSCs related signal pathways, targeting CSC niches, targeting CSC metabolic pathways, inducing differentiation therapy and immunotherapy (tumor vaccine, CAR-T, oncolytic virus, targeting CSCs-immune cell crosstalk and immunity checkpoint inhibitor). We highlight the potential of immunity therapy and its combinational anti-CSC therapies, which are composed of different drugs working in different mechanisms.

Keywords: CSCs; mitotic division pattern; metabolic phenotype; therapeutic resistance; targeted strategy; tumor therapy

\section{Introduction}

Tumors pose a significant threat to human life. The battle against tumors has always been fierce across human society, and many scientists are working on revealing the mechanisms of genesis, progression, recurrence and metastasis of the tumor. Many methods have been proposed to tackle tumors, such as operations, chemotherapy and radiotherapy; however, the consequences are not satisfactory. A previous study showed that cancer ranked 2rd among all of the leading causes of death in the US in 2018 [1]; it even ranked the first in some regions in the US [2]. In recent years, as a kind of revolutionized method, molecular targeted therapies showed many successful aspects in many different cancer types [3]. The key point of molecular targeted therapy is to find a perfect therapeutic target, which can be DNA, RNA, protein or some special molecules located on the tumor cell, and it should be specific, effective and easy to work for the targeted drugs. According to 
the latest reports, the strategies targeting cancer stem cells (CSCs) could be a promising therapeutic strategy [4].

CSCs, also named tumor-initiating cells (TICs), are a subgroup of tumor cells, although the percentage of CSCs is less than approximately $2 \%$ in all tumors [5]; many studies have proven that CSCs were closely related to the genesis, development, metastasis, recurrence and therapeutic resistance of tumor, which could be the reasons for tumor treatment failure [6-8]. CSCs harbor similar properties to stem cells, self-renewal and multipotential differentiation. In addition to self-renewal and multi-directional differentiation properties, CSCs also have a unique mitotic division pattern, unique metabolic phenotype and stubborn resistance to antitumor therapies.

\section{Biological Characteristics}

\subsection{Mitotic Division Pattern of CSCs}

In general, tumor cells showed proliferation, invasion and metastasis characteristics via rapidly symmetric mitotic division; however, different mitotic division modes were observed in CSCs. To adapt to different proliferative conditions and therapeutic stress, researchers found that CSCs could exhibit plasticity by changing their mitotic division pattern. In accordance with previous scientists, stem cells benefited from the facultative phenomenon of symmetric and asymmetric divisions, which enabled them to perpetuate themselves and generate differentiated progeny [9]. It was found that the self-renewal of stem cells could be determined by asymmetric mitosis, which was completed under the regulation of the extrinsic stem cell niche signal to orient the mitotic spindle perpendicularly to the niche surface and the building of intrinsic polarity axis to localize cell fate determinants asymmetrically in mitosis [10]. Some CSCs showed an asymmetric division pattern during their mitosis [11,12]; in this mitotic division pattern, CSCs could acquire cellular asymmetry during the cell division interphase to reorient the polarity axis of the spindle and generate asymmetric division via the reorientation of the distribution of the Par3/Par6/atypical protein kinase $\mathrm{C}$ complex and the microtubule-associated nuclear mitotic apparatus protein (NuMA)/LGN/G $\alpha$ i complex [13]. Subsequently, an asymmetric spindle morphology will form during the division phase in which the apical half spindle is much larger in size than that of the basal half spindle; a progenitor CSC will divide into two differently sized cells; CSC, which harbors the capacity of self-renewal and differentiation potential, and a differential tumor cell, which enters the tumor cell cycle (Figure 1). Different mitotic divisions occur in different tumor types, it was revealed that the division pattern of glioma stem cells was symmetric division, not asymmetric division [14]. In symmetric mitosis, CSCs could be divided into two CSCs or two differentiated tumor cells. Interestingly, researchers found that symmetrical and asymmetrical division patterns could coexist in the oral CSCs [15]. The mitotic division pattern plays a crucial role in tumor development; Sandra G-L et al. suggested asymmetric division as a tumor suppressor and that the loss of asymmetric division phenotypes could contribute to tumorigenesis [9]. Several researchers have revealed that asymmetric division is not the main division pattern of CSCs and even contributed to the evolutionary disadvantage of CSCs during tumor development; however, the asymmetric division also helped CSCs to survive under different therapeutic stress [16]. In summary, the mitotic pattern of CSCs and their related contribution to tumorigenesis remain unclear and controversial; the different cancer types, tumor stages, CSC niche circumstances and different therapeutic stresses decide the different mitotic patterns of CSCs. 


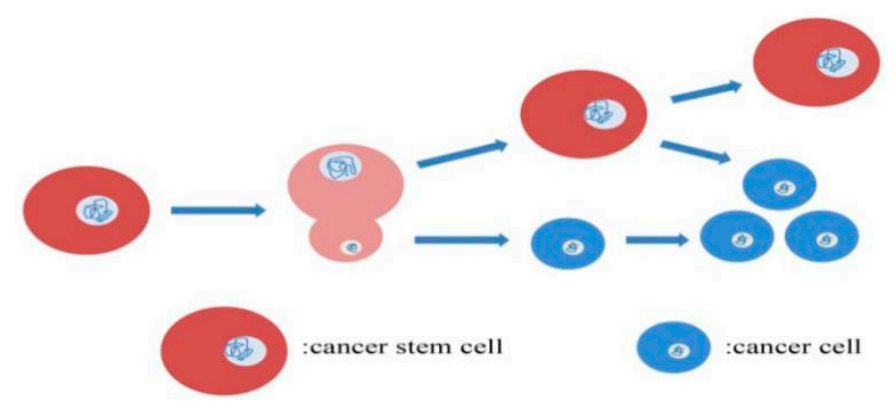

Figure 1. Asymmetric mitotic division pattern of CSCs.

\subsection{Metabolic Pattern of CSCS}

As we know, the energy metabolism of the normal cell occurs in the mitochondrial matrix, and the main productive pathway is always the tricarboxylic acid cycle (TAC) coupled to oxidative phosphorylation (OXPHOS) of the carbon source, including glucose, fatty acid and sometimes protein, glycolysis is another metabolic pattern with properties of faster efficient energy production and lower efficient use of glucose. It was revealed in the Warburg effect, the tumor cell could change its energy metabolic pattern from OXPHOS to aerobic glycolysis to meet its higher metabolic needs due to its faster proliferation property [17]. CSCs are a subgroup of tumor cells, the energy metabolic pattern should be glycolysis according to the Warburg effect, but controversial views have appeared in different studies. It has been indicated in many studies that the metabolic pathway of CSCs should be aerobic glycolysis, which could be initiated by pyruvate dehydrogenase kinase 1 (PDK1) to enhance stemness in mouse model; glycolysis was also found to contribute to breast cancer stem cells (BCSCs) and as a potential therapeutic strategy for breast cancer [18]. What's more, glycolysis was observed to promote an increased stemness phenotype and tumorigenicity in basal-like breast cancer [19]; this metabolic pattern was also found in some other solid tumors. Meanwhile, some researchers have found that OXPHOS could act as a metabolic phenotype in CSCs; for instance, it was indicated that OXPHOS was highly activated in acute myeloid leukemia stem cells [20], it has also been suggested that it could be a strategy to target OXPHOS of BCSCs to reverse the multi-drug resistance (MDR) [21]; the OXPHOS metabolic pattern was also observed in glioblastoma cancer stem cells [22], lung CSCs [23] and some other cancer types. It is interesting that different metabolic patterns can coexist in the same tumor at the same time [24]. Many studies have indicated that the energy metabolic pattern is closely related to regulating the stemness of CSCs. CSCs show dynamic metabolic heterogeneity in different species, tumors, tumor microenvironments and CSC niches [25], which leads to therapeutic limitations in targeting the metabolic pathway of CSCs.

\subsection{Therapeutic Resistance of CSCs}

The tumor dormancy phenomenon has been found in many cancer types, and it has also been revealed that tumor dormancy contributes to therapy resistance, metastasis and immune system evasion; certain CSCs, called dormancy-competent CSCs (DCCs), share some characteristics with dormant tumor cells [26]. CSCs show resistance to conventional therapeutic drugs [27]; common chemotherapy drugs inhibit tumors by inducing DNA damage and inhibiting mitosis [28]; CSCs are not sensitive to chemotherapeutic drugs as they always stay dormant(G0 stage) [5], during which, the DNA damage-repair mechanism of CSCs will be initiated and mediates CSCs escaping from apoptosis [29].

Different concentrations of reactive oxygen species (ROS) play different roles in cell survival, of which, the low concentration of ROS can promote cell adaptive proliferation, the high one will cause permanent damage to DNA, RNA and the other bio-macromolecules in the cell; CSCs can survive in chemotherapy due to their low ROS level caused by the increased ROS scavenger level in CSCs [30]. 
ATP-binding cassette efflux transporters ( $\mathrm{ABC}$ transporters) were membrane proteins which were firstly found in bacteria. $A B C$ transporters were also found as multidrugresistant (MDR) proteins because they could help cancer cells to avoid being eliminated by pumping chemotherapeutic drugs out [31,32] (Figure 2). An increased expression of $A B C$ transporters (ABCB1, $\mathrm{ABCC} 2$ and $\mathrm{ABCG}$ ) was found in CSCs, which contributed to the MDR of CSCs. ABC transporters have been indicated as an ideal target in reversing the MDR of CSCs in many studies [33].

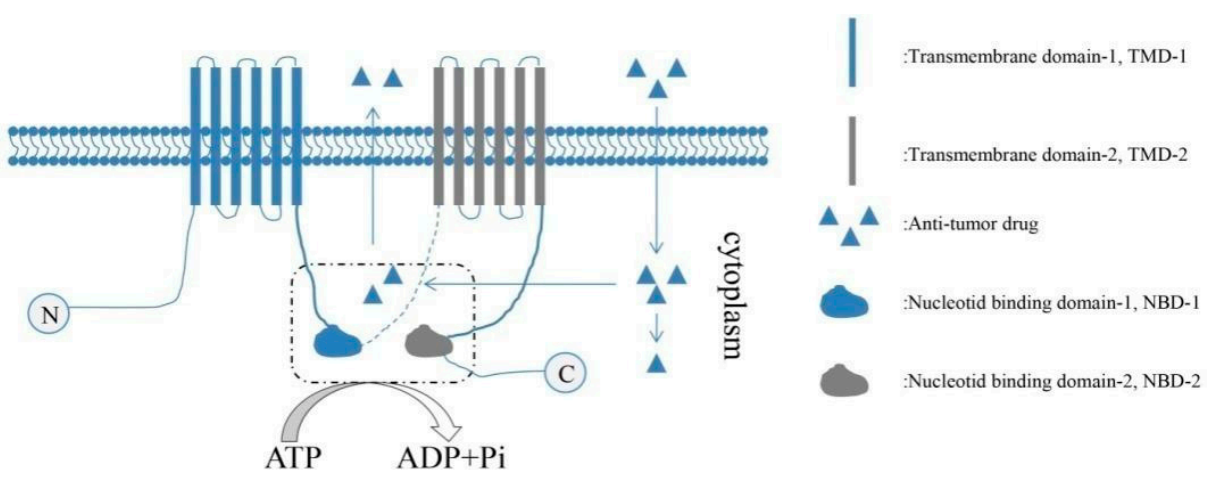

Figure 2. An $A B C$ transporter is composed of two transmembrane domains (TMD-1 and TMD-2) and two nucleotide-binding domains (NBD-1 and NBD-2). As shown in the figure, chemotherapeutic drugs could be pumped out of tumor cells via the ABC transporter expressed on CSCs.

The tumor microenvironment (TME) harbors the capacity to maintain the stemness of CSCs; TME acts as a nest for CSCs, where CSCs can maintain their chemo/radiotherapy resistance via hypoxia, lower vascularization and different nutritional metabolic patterns [34]. Many methods have been proposed to reduce the resistance caused by CSCs. Shen et al. proposed a nanotherapeutic strategy, which was composed of all-trans retinoic acid, differentiation-inducing agent, and chemotherapeutics (camptothecin); it could reduce stemness-related resistance and prevent the mouse models from tumor relapse and metastasis after surgical operation [35]. Toni Nunes et al. proposed a material named gold nanoparticles, which can reverse resistance by functionalizing with antibodies to target CSCs [36].

Many other therapeutic resistance-related mechanisms have been proposed in detail in previous reviews, including increased autophagic activity, decreased ferroptosis, immune escape and favorable tumor vasculogenic mimicry in CSCs; all of these lead to the MDR and radio-resistance (RR) of CSCs in many tumor types [37].

\section{Targeted Strategies of CSCs}

\subsection{Targeting Surface Molecules of CSCS}

CSCs were firstly found in hematological malignancy, which were marked by CD34 ${ }^{+} /$ CD48- [38]; after that, it was found that it was feasible to identify and isolate CSCs from tumor tissues via their surface markers. Subsequently, different CSC surface markers were found in different tumor types (Figure 3), and most of them were found as membrane proteins, which made these membrane proteins ideal antigens to be targeted by several specific antibodies. There is no doubt that the monoclonal antibody is the best choice due to its higher specificity and lower toxicity. The monoclonal antibody has proven its success in tumor therapy; the classic cases such as trastuzumab for HER2 ${ }^{+}$breast cancer and cetuximab for colorectal cancer are well known to us. According to the current knowledge, the monoclonal antibody could kill target cells via several different mechanisms, including antibody-dependent cytotoxicity and complement-dependent cytotoxicity, inhibiting cell signal transduction and inducing cell apoptosis directly. In this regard, researchers have focused on designing different monoclonal antibodies to target CSCs. 


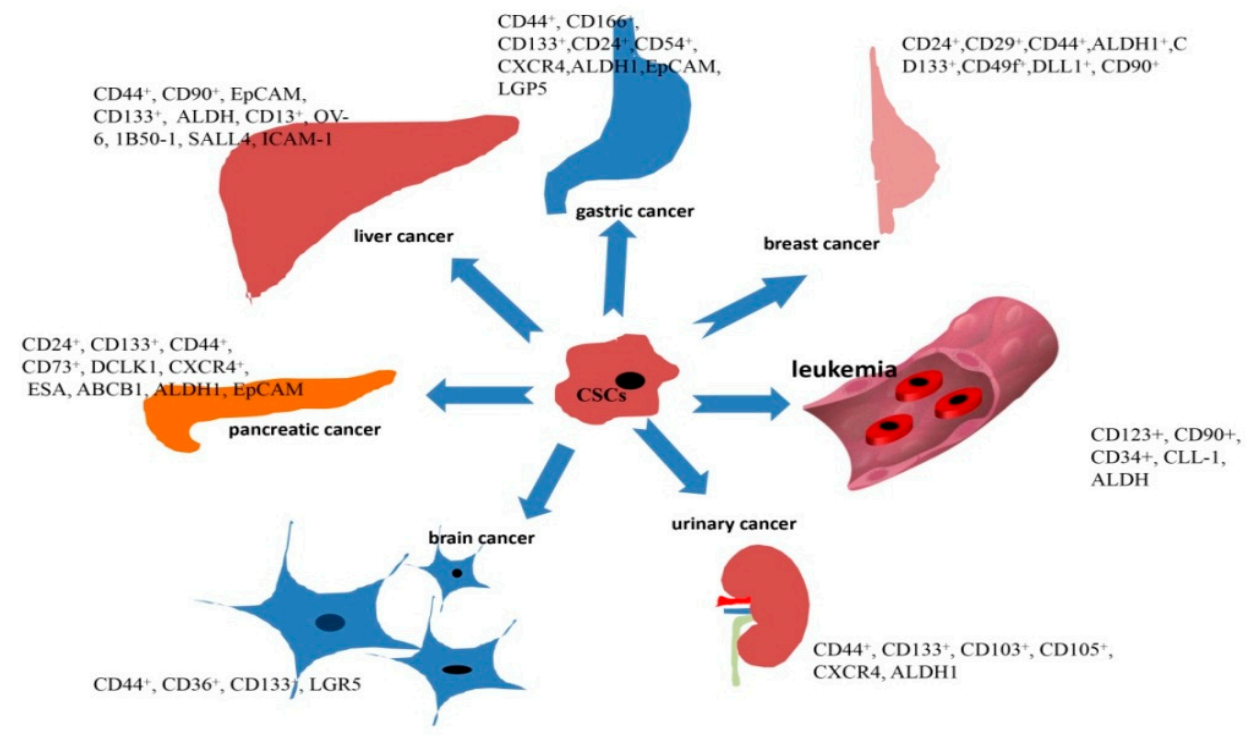

Figure 3. Surface markers expressed on different CSCs.

Adhesion molecules CD44, CD133, and CD90 were found as CSCs markers in many cancer types. Anti-CD44 was thought to be a potential targeting strategy in the treatment of CSCs [39]. Several monoclonal antibodies, such as H90 targeting CD44, 7G3 targeting CD123 and B6H12 targeting CD47, were proved effective in inhibiting leukemia stem cells [40]. RO5429083, a monoclonal antibody targeting CD44, has been evaluated in clinical trials in malignant solid tumors and acute myelogenous leukemia by Roche. The increased tumor-initiating potential of CD90 was observed in athymic nude mice, and the anti-CD90 monoclonal antibody showed its potential to inhibit the stemness of CSCs in malignant insulinoma [41]. There are also some other CSC markers, such as CD54, EpCAM and ALDH, which have been used to target CSCs; many clinical trials have been conducted in different areas, some of which are shown in Table 1.

The present problem is that the percentage of CSCs in cancer tissues is very small; meanwhile, the surface markers expressed on CSCs can also be expressed on normal cells (Table 2), meaning that the drugs targeting CSCs surface markers always show drug toxicity to healthy cells, which makes it difficult to target CSCs accurately. Thus, it is urgently needed to find more specific targeting markers to target CSCs in future research. 
Table 1. Some agents targeting surface markers of CSCs which have been evaluated in clinical trials.

\begin{tabular}{|c|c|c|c|c|c|}
\hline Agents & Target & NCT Number & Phase & Current State & Condition \\
\hline \multirow[t]{2}{*}{ BIWA1 } & CD44v6 & NCT02204046 & I & Completed & Breast cancer \\
\hline & & NCT02204059 & I & Completed & Lung cancer \\
\hline \multirow[t]{2}{*}{ RO5429083 } & CD44 & NCT01358903 & I & Completed & Malignant solid tumors \\
\hline & & NCT01641250 & I & Completed & Leukemia \\
\hline $17-1 \mathrm{~A}$ & EpCAM & NCT02915445 & & Recruiting & $\begin{array}{c}\text { Nasopharyngeal/breast } \\
\text { cancer }\end{array}$ \\
\hline \multirow{5}{*}{ Catumaxomab } & & NCT00309517 & & Terminated & Rectal carcinoma \\
\hline & EpCAM & NCT01815528 & II & Completed & Ovarian cancer \\
\hline & & NCT01246440 & II & Completed & Ovarian cancer \\
\hline & & NCT00326885 & II & Completed & Malignant ascites \\
\hline & & NCT00464893 & II & Completed & Gastric cancer \\
\hline Adecatumumab & EpCAM & NCT00866944 & II & Completed & $\begin{array}{l}\text { Colorectal liver } \\
\text { Metastases }\end{array}$ \\
\hline ING-1 & EpCAM & NCT00051675 & I & Completed & Adenocarcinomas \\
\hline Edrecolomab & EpCAM & NCT00002968 & III & Completed & Colon cancer \\
\hline CSL-360 & CD123 & NCT00401739 & I & Completed & Acute Leukemia \\
\hline Talacotuzumab & CD123 & NCT02472145 & II/III & Completed & Acute Leukemia \\
\hline anti-ICAM-1 Mab & CD54 & NCT01025206 & I & Completed & Multiple myeloma \\
\hline
\end{tabular}

Table 2. Surface markers expressed on the CSCs could also be expressed on the normal organs/cells.

\begin{tabular}{cll}
\hline Surface Marker & \multicolumn{1}{c}{ CSCs } & \multicolumn{1}{c}{ Normal Cells/Organs } \\
\hline \multirow{2}{*}{ CD44 } & $\begin{array}{l}\text { Liver [42], stomach [43], breast [44], } \\
\text { pancreas [45], glioma [46], kidney [47], } \\
\text { colon, rectum [48] }\end{array}$ & $\begin{array}{l}\text { Lymphocytes [62], vascular endothelial cells [63] } \\
\text { corneal cells [64], astrocytes [65], mucosal cells [66] } \\
\text { intestinal epithelial cells [67] }\end{array}$ \\
\hline CD29 & $\begin{array}{l}\text { squamous cell carcinoma [49], } \\
\text { breast [50], colon [51] }\end{array}$ & $\begin{array}{l}\text { vascular endothelial cells [68], salivary glands [69] } \\
\text { myoepithelial cells [70], epithelial cells [71] }\end{array}$ \\
\hline CD54 & prostate [52], breast [53] & hematopoietic cells [72,73] \\
\hline CD123 & leukemic stem cells [54] & testis [74], lung, brain [75], basophil [76] \\
\hline ALDH & stomach [55], breast [56], pancreas [57], & breast stem cells [77], \\
kidney [58], colon [59] squamous cancer [60] & renal tubular stem cells [78] \\
\hline CD73 & pancreas [61] & $\begin{array}{l}\text { lymphatic endothelial cells [79], } \\
\text { vascular endothelial cells [80] }\end{array}$
\end{tabular}

\subsection{Targeting Signal Pathways of CSCs}

In recent years, increased studies have proven that properties of CSCs could be regulated by different signal pathways, including Wnt, Notch, NF-kB, Hh, JAK-STAT, PI3K-AKT-mTOR, TGF- $\beta$ and PPAR; most of these signal pathways are closely related to cell fate, and the abnormal activation of these signal pathways always contributes to tumor cell proliferation, differentiation, metastasis, recurrence and MDR via the regulation of CSCs in different tumor types. It was revealed that the Wnt signal pathway contributes to the stemness of CSCs, and some researchers have proposed that the stemness of CRC CSCs can be defined by high Wnt activity [81]. Paloma Ordóñez-Morán et al. found that the expression of HOXA5 could inhibit the activation of the Wnt pathway, induce the loss of CSC phenotypes, and prevent tumor development and metastasis in colon cancer [82]. The novel activation of Wnt and Notch signal pathway was observed in renal CSCs, and it was found that it could block the self-renewal and proliferation of renal CSCs by inhibiting such signal pathways [83]. The Hh signal pathway also contributes to the stemness of CSCs in several aspects; Mingli Zhou et al. indicated that the activated Hh signal pathway could enhance the expression of CSCs TFs (SOX2, OCT4) and they suggested that the stemness of CSCs could be gained by activating the Hh signal pathway [84]. Lipid desaturation was proved to be a metabolic marker for ovarian cancer stem cells, and its expression level could 
be directly regulated by the NF-kB signal pathway [85]. JAK2-STAT3 was overexpressed in the CRC stem cell, and the targeting gene cyclin D2 (CCND2) was increasingly transcribed to maintain the properties of CRC CSCs, such as proliferation and radio-resistance [86]. EMT, CSCs phenotypes and PI3K-AKT-mTOR signal pathway proteins were increasingly expressed in prostate cancer radio-resistant cell lines, and it was demonstrated that $\mathrm{CaP}$ radio-resistance was closely related to EMT and enhanced CSC phenotypes, which were mediated by the activation of the PI3K-AKT-mTOR signal pathway. Researchers found that the excessive activation of the TGF- $\beta$ signal pathway could enhance the stemness of CSCs in triple-negative breast cancer (TNBC); they suggested that the combination of classical chemotherapy agents and TGF- $\beta$ inhibitors could improve the prognosis of TNBC [87]. Some non-steroidal anti-inflammatory drugs (NSAIDs), such as aspirin and indomethacin, could decrease the stemness of CRC CSCs by activating PPAP- $\gamma$ [88]. Several other signal pathways have been less frequently reported in connection with CSCs; COX2 was found to be related to contributing to CSC phenotypes, such as apoptosis resistance, cell proliferation and MDR, via its metabolite prostaglandin E2, so researchers proposed that the COX2 signal pathway would be a potential target for anti-CSCs [89]. Obviously, the crucial role of CSCs in tumor development was regulated by many different signal pathways; thus, it is a logical strategy to eliminate CSCs and improve prognosis via inhibiting the signal pathways of CSCs [90].

\subsubsection{Notch Signal Pathway Inhibitor $\gamma$-Secretase Inhibitors (GSIs)}

As we know, the core step of the Notch signal pathway is the release of Notch intracellular domain(NICD). GSIs can prevent the release of NICD from the proteolytic cleavage of Notch receptors, GSIs have been proven to develop successfully in many different tumors and have also been suggested to be a targeting strategy in triple-negative breast cancer (TNBC) [91]; researchers have revealed that therapeutic sensitivity to GSIs could be influenced by NOTCH-1 mutations in TNBC [92]. A similar result was also observed in CRC [93]. RO4929097 is a kind of GSI; a single-agent strategy of RO4929097 showed its limitations in advanced tumors in many clinical trials, including metastatic melanoma [94], metastatic CRC [95] and recurrent ovarian cancer [96]. Thus, combinational therapeutic strategies have been suggested to inhibit CSCs via blocking the Notch signal pathway; for example, the safety of the combination of RO4929097 and temsirolimus has been proven in solid tumor treatment [97]. The combination of GSIs with trastuzumab and lapatinib could reduce tumor growth and recurrence in breast cancer [98]. It has also been indicated that the combination of GSIs and MAPK could enhance their pesticide effects in CRC cell lines [99].

\section{Anti- Delta-like Ligand 4 (DLL4) Monoclonal Antibody}

DLL4is known for its function in tumor angiogenesis. The angiogenesis of functional capillaries plays a crucial role in tumor development, and it has been reported that the expression of DLL4 could be regulated by vascular endothelial growth factor (VEGF) on vascular endothelial cells. The increased formation of non-productive angiogenesis could be induced by blocking DLL4; this process showed its anti-tumor potential $[100,101]$. REGN421 (enoticumab) is a human IgG1 monoclonal antibody, which can inhibit the Notch signal pathway via binding to DLL4; it was observed to inhibit tumor growth by the formation of non-functional capillaries in ovarian tumor xenograft models. The combination of REGN421 with VEGF inhibitor was also suggested as a better strategy in this study [102]. Enoticumab has been proven to be safe and effective in clinical trials [103]. DLL4 inhibitor, either alone or in combination with another DLL4 inhibitor or irinotecan, showed its therapeutic value in xenograft tumor models [104]. 


\subsubsection{Hedgehog(Hh) Signal Pathway Inhibitor}

Aberrant activation of the Hh signal pathway is closely related to tumorigenesis, metastasis and recurrence, and it is a good point to improve prognosis by inhibiting the Hh signal pathway. Targets to inhibit the Hh signal pathway include the Hh ligand, Hh receptor and $\mathrm{Hh}$ transcription factor, which are an SMO inhibitor, Gli inhibitor and $\mathrm{SHH}$ inhibitor, respectively. SMO is an Hh receptor encoded by oncogene smooth; it can mediate Gli to enter the nucleus to initiate the expression of downstream genes. SMO inhibitors have shown their therapeutic value when used alone or in combination with other chemotherapy drugs. Sonidegib has been found to downregulate the expression of SMO and Gli in human natural killer/T-cell lymphoma cells, and researchers have shown its anti-tumor targeting potential [105]. PF-04449913 is an SMO inhibitor, it has been used to treat myeloid malignancies in many clinical trials [106,107]. BMS-833923 is an SMO antagonist, which was identified as a powerful inhibitor in human skeletal stem cells [108]; it was indicated that GFC-0449 could inhibit proliferation and induce apoptosis in CRC cell lines [109]. GFC-0449 was also proved to be a potential treatment in cholangiocarcinoma [110]. Gli is a core transporter factor (TF) in the Hh signal pathway. GANT58 and GANT61 were found as Gli inhibitors, they could inhibit the transcriptional activity of Gli1 in the nucleus, and GANT61 showed better potential in prostatic cell lines [111]. GANT58 was a potential strategy in acute T-cell leukemia cells, and its combined use with AKT inhibitor showed a better therapeutic effect [112]. GANT61 was found to reduce proliferation and cell viability after chemotherapy by the downregulation of CSC-related genes (Oct4, CD44, ALDH and Bmi1) in hepatocellular carcinoma. Zhihua Zhang et al. revealed that GANT61 could induce apoptosis and inhibit proliferation and cell G1/G0 cycle in a dose- and time-dependent manner in multiple myeloma [113], and it was also found to sensitize glioma cells to temozolomide [114]. It was revealed that Arsenic Trioxide could inhibit the growth of human cancer cells by blocking the Hh/Gli pathway in vivo and in vitro [115], and its clinical value has been proven in many studies. There are also some Hh inhibitors whose targets are Hh signal pathway ligands, such as Shh inhibitors, RU-SKI43 and Shh monoclonal antibody 5E1, which have been mentioned in previous studies [116].

\subsubsection{Wnt Signal Pathway Inhibitor}

It was revealed that the Wnt signal pathway participated in many cancer processes, including glycolysis, glutaminplysis, lipogenesis, the metabolic negative feedback loop and cancer immunotherapy [117], indicating its potential to inhibit tumor development via targeting the Wnt signal pathway. It was summarized that the Wnt signal pathway inhibitors could be divided into two types, secreting inhibitors, which included Dickkopf proteins (Dkks), secreted Frizzled-related proteins (sFRPs), Wnt-inhibitory factor 1 (WIF1), Wise/SOST, Cgeberus and insulin-like growth factor binding protein 4 (IGFBP-4), and transmembrane inhibitors, which included Shisa, Wnt-activated inhibitory factor 1 (Waif1/5T4), adenomatosis polyposis coli downregulated 1 (APCDD1) and Tiki1 [118]. Many studies have focused on their functions in tumor therapy; Youcheng Shao et al. showed the diagnosis and therapeutic value of Dkks in their study [119]. It was found that sFRPs harbored a biphasic regulating function in the Wnt- $\beta$ catenin signal in CSCs [120], the process of which may be determined by the cellular context and concentration of Fzd receptors [121]. Shisa3 was revealed as a tumor suppressor and a new insight for tumor prognosis and therapy [122]; it could be a biomarker for patients suffering from chronic lymphocytic leukemia, regardless of whether they could benefit from lenalidomide treatment [123]. Many Wnt inhibitors have been investigated in many clinical or preclinical trials, such as CGX1321, LGK974 andDKN-01, and some of them have been approved by the FDA to solve clinical problems.

\subsubsection{Other Signal Pathway Inhibitors}

As mentioned before, CSCs are regulated by many other signal pathways; except for Wnt, Notch and Hh, researchers have also tried to inhibit CSCs via these signal path- 
ways. The TGF- $\beta$ signal pathway plays a biphasic role in tumor progression; it also plays crucial roles in EMT and TME. Different inhibitors, targeting TGF- $\beta$, the TGF- $\beta$ receptor, the TGF- $\beta$ ligand and their interaction have been designed in previous studies. The anti-tumor activity of some antibodies, such as 264RAD and GC1008, has been proven; meanwhile, some small molecules that target $\mathrm{T} \beta \mathrm{R}$ kinase, such as galunisertib, were also proven to be effective in hepato-cellular cancer and pancreatic cancer [124]; several TGF- $\beta$ inhibitors have been evaluated in clinical trials. The abnormal activation of the JAK/STAT signal pathway promotes tumorigenesis, and many JAK/STAT signal pathway inhibitors, such as JAK inhibitors (INCB018424 and AZD1480), STAT inhibitors (STAT3 inhibitor and STAT5 inhibitor) and phytochemicals(phenolics, polyphenols, terpenoids, alkaloids, saponins, steroids, lignin and phytoalexin) were found to inhibit tumor growth [125]. $\mathrm{PI} 3 \mathrm{~K} / \mathrm{AKT} / \mathrm{mTOR}$ was frequently activated in many human tumors; it also contributes to CSCs in many aspects. Researchers found its feasibility to inhibit tumor development via blocking PI3K/AKT/mTOR, which could be divided into PI3K inhibitor (AZD8835, CUDC907 and GDC0077), AKT inhibitor (ARQ092, AZD5363 and MK2206) and mTOR inhibitor (Ridaforolimus, Sirolimus and Evcrolimus); many of them have been proven to be safe and effective in clinical trials, and some of them, such as Zydelig, Copanlisib, Rapamycin and Sirolimus, have been approved for human cancer treatment by the FDA, except for application in tumor therapy. The off-target effects and some adverse reactions, such as hypoglycemia, pneumonitis and neuropsychiatric effects, are also huge problems to solve in the future [126]. Some PPAR agonists, such as Pioglitazone, also showed tumor inhibition in a previous study [127].

Although the strategies targeting the signal pathway contributed to inhibiting CSCs in many aspects, many related agents have been tested in clinical trials, as shown in Table 3; however, controversial views remain in this field. CSCs are regulated by crosstalk among various signal pathways, and some researchers have found that some agents could promote another tumorgenesis-correlated signal pathway while they working as inhibitors to block the anti-tumor-correlated signal pathway [128]. Toxicity, adverse reactions and drug resistance caused by the gene mutation of components in different signal pathways are also common problems that need to be solved.

Table 3. Some agents targeting CSCs-related signal pathways which were evaluated in clinical trials.

\begin{tabular}{cllccc}
\hline Drug Name & Target & NCT Number & Phase & Current State & Condition \\
\hline RO4929097 & Notch & NCT01120275 & II & Terminated & Melanoma \\
& & NCT01238133 & I & Terminated & Breast cancer \\
& & NCT01175343 & II & Completed & Ovarian cancer \\
& & NCT01154452 & I/II & Completed & Sarcoma \\
& & NCT01198535 & I & Terminated & Colorectal cancer \\
& & NCT01232829 & II & Completed & Pancreatic cancer \\
& & NCT01122901 & II & Terminated & Glioblastoma \\
LY90009 & NCT01131234 & I & Completed & Solid tumors \\
MK-0752 & Notch & NCT01158404 & I & Completed & Advanced tumors \\
& & NCT00645333 & I/II & Completed & Breast cancer \\
OMP-54F28 & NCT00106145 & I & Completed & Breast cancer \\
& Wnt & NCT00572182 & I & Terminated & CNS cancer \\
& & NCT02069145 & I & Completed & Hepatocellular cancer \\
& & NCT02092363 & I & Completed & Ovarian cancer \\
LGK974 & NCT02050178 & I & Completed & Pancreatic cancer \\
WNT974 & NCT01608867 & I & Completed & Solid tumors \\
DKN01 & Wnt & NCT01351103 & I & Recruiting & Malignancies \\
& Wnt & NCT02278133 & II & Completed & colorectal cancer \\
& Wnt & NCT04681248 & & Available & Solid tumors \\
& & NCT01457417 & I & Completed & Recruiting
\end{tabular}


Table 3. Cont.

\begin{tabular}{|c|c|c|c|c|c|}
\hline Drug Name & Target & NCT Number & Phase & Current State & Condition \\
\hline \multirow[t]{3}{*}{ BMS-833923 } & $\mathrm{Hh}$ & NCT00670189 & $\mathrm{I}$ & Completed & Advanced cancer \\
\hline & & NCT01413906 & $\mathrm{I}$ & Completed & Solid tumors \\
\hline & & NCT01357655 & II & Completed & Chronic myeloid leukemia \\
\hline \multirow[t]{2}{*}{ GDC-0449 } & $\mathrm{Hh}$ & NCT01088815 & II & Completed & Pancreatic cancer \\
\hline & & NCT00607724 & $\mathrm{I}$ & Completed & solid tumors \\
\hline AVID200 & TGF- $\beta$ & NCT03834662 & $\mathrm{I}$ & Active & Malignancies \\
\hline \multirow[t]{3}{*}{ LY2157299 } & TGF- $\beta$ & NCT02452008 & II & Recruiting & prostatic cancer \\
\hline & & NCT02240433 & $\mathrm{I}$ & Completed & Hepatocellular cancer \\
\hline & & NCT02688712 & II & Recruiting & Rectal cancer \\
\hline \multirow[t]{2}{*}{ GC1008 } & TGF- $\beta$ & NCT01112293 & II & Completed & Mesothelioma \\
\hline & & NCT01401062 & II & Completed & breast cancer \\
\hline \multirow[t]{2}{*}{ Itacinib } & JAK-STAT & NCT04358185 & II & Recruiting & hepatocellular cancer \\
\hline & & NCT03989466 & $\mathrm{I}$ & Recruiting & $\begin{array}{l}\text { T-Cell prolymphocytic } \\
\text { Leukemia }\end{array}$ \\
\hline \multirow[t]{4}{*}{ Ruxolitinib } & JAK-STAT & NCT04906746 & $\mathrm{I}$ & Not recruiting & Lung cancer \\
\hline & & NCT01895842 & $\mathrm{I}$ & Completed & Leukemia \\
\hline & & NCT03514069 & $\mathrm{I}$ & Recruiting & Glioma \\
\hline & & NCT01594216 & III & Completed & breast cancer \\
\hline \multirow[t]{3}{*}{ SB1518 } & JAK-STAT & NCT00719836 & $\mathrm{I} / \mathrm{II}$ & Completed & Myeloid malignancies \\
\hline & & NCT04635059 & & Recruiting & Prostate cancer \\
\hline & & NCT02323607 & $\mathrm{I}$ & Completed & Acute myeloid leukemia \\
\hline \multirow[t]{3}{*}{ Alpelisib } & $\mathrm{PI3K} / \mathrm{AKT} / \mathrm{mTOR}$ & NCT04526470 & II & Not recruiting & Gastric cancer \\
\hline & & NCT04544189 & II & Recruiting & Breast cancer \\
\hline & & NCT01300962 & $\mathrm{I}$ & Completed & Breast cancer \\
\hline \multirow[t]{2}{*}{ Temsirolimus } & $\mathrm{PI3K} / \mathrm{AKT} / \mathrm{mTOR}$ & NCT01072890 & $\mathrm{I}$ & Completed & Solid tumors \\
\hline & & NCT01050985 & $\mathrm{I}$ & Completed & Advanced malignancies \\
\hline \multirow[t]{2}{*}{ Copanlisib } & $\mathrm{PI3K} / \mathrm{AKT} / \mathrm{mTOR}$ & NCT03498430 & $\mathrm{I}$ & Completed & $\begin{array}{l}\text { Non-Hodgkin's } \\
\text { lymphoma }\end{array}$ \\
\hline & & NCT04750941 & II & Recruiting & Endometrial cancer \\
\hline \multirow[t]{3}{*}{ Capivasertib } & $\mathrm{PI3K} / \mathrm{AKT} / \mathrm{mTOR}$ & NCT04742036 & $\mathrm{I}$ & Recruiting & Solid Tumors \\
\hline & & NCT04087174 & $\mathrm{I}$ & Completed & Prostate cancer \\
\hline & & NCT04862663 & $\mathrm{I} / \mathrm{III}$ & Recruiting & Breast cancer \\
\hline Pioglitazone & PPAR & NCT02133625 & I & Completed & Solid tumors \\
\hline
\end{tabular}

\subsection{Targeting Metabolic Pathways of CSCs}

As mentioned before, CSCs harbor a unique energy metabolic pattern. Targeting CSCs metabolism has been found to potentially eliminate CSCs. Metformin and phenformin, which are well known for their anti-diabetes function, were found to inhibit tumor growth via targeting CSCs, including gastric cancer [129], colorectal cancer [130], ovarian cancer [131] and prostate cancer [132]. The mechanism could be explained by its ability to inhibit mitochondrial function. It was revealed that Metformin could reduce tumorigenesis by inhibiting mitochondrial complex I [133]. Cancer therapy benefits from some antibiotics, which have been proven to inhibit the respiratory function of mitochondria; for example, salinomycin showed anti-tumor activity in colorectal cancer [134], and it was also indicated that mitochondrial function could be disrupted by salinomycin $[135,136]$. ROS are produced in the electron transport chain(ETC) during cell energy metabolism, as found in previous studies, a lower ROS level was observed to maintain CSC properties in CSC niche, thus, eliminating CSCs via a ROS inducer was proposed. Disulfiram and copper could induce apoptosis by increasing the ROS level in ovarian CSCs, which were marked by $\mathrm{ALDH}^{+}$[137]. The manganese(ii)-3,4,7,8-tetramethyl-1,10-phenanthroline complex comprises polymeric nanoparticles and has been indicated to be able to reduce CSC properties by producing ROS in BCSCs [138]. Mitochondrial fatty acid oxidation(FAO) was proven to be necessary in breast cancer stem cells [139]. Etomoxir is an FAO inhibitor; it can suppress tumor development in bladder cancer [140] and nasophanryngeal cancer [141]. Meanwhile, the metabolism of CSCs is influenced by some signal pathway inhibitors; sFRP4 is a Wnt in- 
hibitor, which was revealed to be able to inhibit CSC survival by regulating its metabolism in breast and prostate cancer stem cell lines [142]. Some strategies mentioned in previous studies have focused on transporting drugs to mitochondria efficiently and accurately, for example, the conjugation of targeting mitochondrial drugs to triphenylphosphonium (TPP) or mitochondria-penetrating peptides(MPP) [143]. This strategy also promoted a combination of targeting metabolism drugs with conventional chemotherapy to improve the therapeutic effect. This seems to be a potential strategy to reduce tumors via targeting glycolysis and there have been many studies focused on this field; it was summarized that the main targeting glycolysis therapies include glucose deprivation, GLUT inhibitors, HK-II inhibitors, PFK inhibitors, GAPDH inhibitors, PK-M2 inhibitors and LDH inhibitors [144], and some of them have been proven to have anti-tumor potential. However, this is limited due to its serious adverse systemic reaction in trials, and some of them were even indicated to have a pro-survival role in cancer cells [145]. Thus, the accurate targeting and combination of glycolysis inhibitors must be investigated in more studies and clinical trials. Due to its metabolic heterogeneity in CSCs, some researchers proposed the "two metabolic hit" strategy, during which the glycolysis inhibitors would be used to eliminate CSCs after the first use of mitochondrial inhibitors [146]. Although many metabolic agents have been evaluated in clinical trials (Table 4), an obvious limitation was observed when these agents were used alone. Thus, a combinational strategy consists of different anti-glycolysis and anti-OXPHOS drugs, and conventional chemotherapy drugs might be a better option.

Table 4. Some agents targeting metabolic pathways of CSCs which have been evaluated in clinical trials.

\begin{tabular}{|c|c|c|c|c|c|}
\hline Agents & Target & NCT Number & Phase & Current State & Condition \\
\hline \multirow{5}{*}{ Metformin } & \multirow{5}{*}{ OXPHS } & NCT00897884 & & Completed & Breast cancer \\
\hline & & NCT01266486 & II & Completed & Breast cancer \\
\hline & & NCT01243385 & II & Completed & Prostate cancer \\
\hline & & NCT02437656 & II & Completed & Rectal cancer \\
\hline & & NCT03359681 & & Recruiting & Colon cancer \\
\hline \multirow[t]{4}{*}{ Disulfiram } & \multirow[t]{4}{*}{ OXPHS } & NCT01118741 & & Completed & Prostate cancer \\
\hline & & NCT02678975 & & Completed & Glioblastoma \\
\hline & & NCT03584009 & II & Completed & Breast cancer \\
\hline & & NCT03000257 & $\mathrm{I}$ & Not yet recruiting & Solid tumors \\
\hline \multirow[t]{4}{*}{ Venetoclax } & \multirow[t]{4}{*}{ BCL-2 } & NCT03082209 & $\mathrm{I}$ & Recruiting & Solid tumors, \\
\hline & & & & & Hematologic malignancies \\
\hline & & NCT04161885 & III & Recruiting & Acute myeloid leukemia \\
\hline & & NCT02265731 & $\mathrm{I} / \mathrm{I}$ & Completed & $\begin{array}{c}\text { Hematological } \\
\text { malignancie }\end{array}$ \\
\hline \multirow[t]{2}{*}{ Ketoconazole } & \multirow[t]{2}{*}{ HK-II } & NCT03763396 & & Not yet recruiting & Glioma \\
\hline & & NCT01036594 & & Completed & Prostate cancer \\
\hline 2-DG & Glut & NCT00096707 & $\mathrm{I}$ & Completed & Solid tumors \\
\hline
\end{tabular}

\subsection{Targeting CSC Niches}

The tumor microenvironment (TME) is the shelter where tumor cells live and proliferate, which is composed of matrix components, cellular components and soluble factors. Many studies focused on TME have indicated that TME contributes to proliferation, invasion, metastasis and immune-escaping of tumor cells. In sum, CSCs are tumor cells, CSC niches are also part of TME. There is a complicated interaction between CSC and CSC niches; it was summarized that CAF could regulate the proliferation, expansion and self-renewal via secreting some cytokines, such as CCL2, IGF-1, TGF- $\beta$ and HMGB-1; what's more, researchers found that CAF could induce tumor cells dedifferentiated change via secreting HGF. [147] The hypoxia environment caused by the faster proliferation and higher energy demand of CSCs was found to contribute to CSC development, especially in solid tumors $[148,149]$. Hypoxia-induced factors (HIFs) cause an adaptation for CSCs to become survivable in the hypoxia environment, including changing the metabolic pattern [150] and up-regulating the expression of multipotential genes, such as Oct4 and 
Sox2 [151]. Many studies have focused on HIFs, especially HIF- $\alpha$, which was revealed to cause increasing stemness and MDR in colorectal cancer via the GLI 2 signal pathway [152]. The downregulation of HIF- $2 \alpha$ could inhibit CSC stemness and induce CSC apoptosis via the AKT-mTOR signal pathway in TNBC [153]; a similar function was also observed in other tumor types. Cancer-associated fibroblasts (CAFs) contribute to the stemness of CSCs by secreting functional proteins and exosomes or activating different CSC-related signal pathways [154]. It was indicated that CAFs could promote stemness properties such as self-renewal, metastasis and chemotherapeutic resistance in CSCs marked by CD24+ [155]. Other components of CSC niches, such as perivascular cells, inflammatory cells, the extracellular matrix (ECM) and some secreted cell factors (VEGF and HGF), were also found to be crucial in promoting proliferation and maintaining stemness in CSCs.

All of the evidence shows the potential to eliminate CSCs by targeting CSC niches. As listed in Figure 3, CXCR4 is a well-known CSC marker in many different cancer types, the crosstalk between CXCR4 and its ligand CXCL12 plays a crucial role in tumor development, also in CSC; it was summarized that CXCL12-CXCR4/CXCR7 axis could maintain CSCs stemness via modulating immune cell migration, recruitment of mesenchymal stem cells, formation of CAFs and vascular endothelial cells, thus, it's a potential strategy to inhibit CSC niches via targeting CXCL12-CXCR4/CXCR7 axis [156]; some CXCR4/CXCR7 inhibitors listed in Table 5 have been evaluated in different clinical trials. Meanwhile, it may be another way to disrupt CSC niches via inhibiting HIF, a feedback loop composed of HIF- $1 \alpha$ and SENP1 existed in the hepatocellular carcinoma, and it was indicated that the positive feedback loop was closely related to the increasing stemness of hepatocellular cancer stem cells and a potential target for HCC therapy [157]. The nanomaterial, called Gd@C $82(\mathrm{OH}) 22$, was found to enhance CSC elimination by inhibiting HIF-1 $\alpha$ and TGF- $\beta$ in breast cancer stem cells [158]. Many HIF inhibitors have been tested their antitumor effect in preclinical and clinical trials, although there is no novel evidence to indicate that these HIF inhibitors work through inhibit CSC niche, it may be a potential mechanism which needs to be found in the future, we list some HIF inhibitors in Table 5. Targeting CAFs is another effective strategy to target CSC niches; there is a crosstalk between CAFs and CSCs, and many strategies have been designed from the crosstalk, including inducing the depletion of CAFs harboring CSC-supporting activities and targeting the signal pathway existing in the CAFs-CSCs crosstalk [154]. Many CAFs-CSCs crosstalk-related signal pathway inhibitors have shown their inhibiting function in CAFs, such as LGK974 and OPB-31121. CAFs could be marked by some cell surface molecules, and it has been revealed that CAFs marked by CD10+ or GPR77+ could be ideal targets to inhibit CSCs in solid tumors [159]. As mentioned before, angiogenesis contributes to CSCs survival; it is a good strategy to eliminate CSCs via inhibiting angiogenesis in CSC niches. Vascular endothelial growth factor (VEGF) plays a crucial role in tumor development, and many studies have shown its therapeutic function in CSCs via blocking VEGR or VEGFR [160]. Endothelial mesenchymal transformation (EMT) is a key characteristic of stem cells; it plays a crucial role in carcinogenesis. Tumor cells show stronger capabilities of proliferation, differentiation and invasion via regulating EMT, and the EMT phenotype contributes to the MDR of tumor cells; it is also closely related to CSCs in many aspects. Researchers have revealed that the expression of surface markers of CSCs, such as CD44 and ALDH, could be regulated by the expression of transcription factors of EMT, such as TWIST, SNAIL and SLUG [161-163]. EMT also shares many of the same signal pathways, such as TGF- $\beta$ and $\mathrm{Hh}$ with CSCs and it was proposed that EMT may be the reason for the acquisition or maintenance of the stemness of CSCs; it was found that the stemness of CSCs and EMT could be regulated by some signal pathway inhibitors, and targeting the EMT phenotype could potentially inhibit tumor cells, even CSCs. GSK3 $\beta$ inhibitors have been identified as EMT inhibitors; it was indicated that GSK3 $\beta$ inhibitors acted as selective inhibitors of EMT and CSCs in TNBC [164]. Some micro-RNAs have proven their function in EMT and CSC regulation in previous studies [165], including some onco-miRNA, such as miR-191, in promoting EMT and increasing the stemness of CSCs in breast cancer [166], and some 
anti-onco-miRNA, such as miR-34a, in inhibiting EMT and CSCs in head and neck squamous cell carcinoma (HNSCC) [167]. Some other strategies have also been proposed, such as targeting chemokine receptors to inhibit CSCs in CSC niches. Obviously, targeting CSC niches is a potential strategy to inhibit CSCs; some agents, such as VEGF inhibitors and HIF inhibitors have been proven to be valid and safe in many clinical trials (Table 5), CSC niches form a complicated environment for CSCs; thus, more detailed components in the niche and more specific targets need to be found to target CSCs in further studies and clinical trials.

Table 5. Some agents targeting CSC niches and inducing differentiation which have been evaluated in clinical trials.

\begin{tabular}{|c|c|c|c|c|}
\hline Agents & NCT Number & Phase & Current State & Condition \\
\hline \multicolumn{5}{|l|}{ CSCs niche inhibitor } \\
\hline \multirow[t]{2}{*}{ LY2510924 } & NCT02652871 & $\mathrm{I}$ & Completed & Acute myeloid leukemia \\
\hline & NCT01439568 & II & Completed & Lung cancer \\
\hline BKT140 & NCT01010880 & $\mathrm{I} / \mathrm{II}$ & Completed & Multiple myeloma \\
\hline AMD3100 & NCT00512252 & $\mathrm{I} / \mathrm{II}$ & Completed & Acute myeloid leukemia \\
\hline BL-8040 & NCT01838395 & II & Completed & Acute myeloid leukemia \\
\hline \multirow[t]{3}{*}{ Bevacizumab } & NCT01190345 & II & Completed & Breast cancer \\
\hline & NCT01137968 & II & Completed & Lung cancer \\
\hline & NCT03632798 & III & Recruiting & Ovarian cancer \\
\hline \multirow[t]{3}{*}{ Topotecan } & NCT00320983 & I & Completed & Cervical cancer \\
\hline & NCT00477282 & III & Completed & Epithelial ovarian cancer \\
\hline & NCT01630018 & II & Completed & Ovarian cancer \\
\hline \multirow[t]{3}{*}{ Digoxin } & NCT01162135 & II & Completed & Prostate cancer \\
\hline & NCT00650910 & $\mathrm{I}$ & Completed & Breast cancer \\
\hline & NCT02106845 & $\mathrm{I}$ & Completed & Solid tumors \\
\hline \multirow[t]{2}{*}{ PT2385 } & NCT03216499 & II & Completed & Recurrent glioblastoma \\
\hline & NCT04989959 & $\mathrm{I}$ & Recruiting & Renal cell cancer \\
\hline \multirow[t]{2}{*}{ EZN-2986 } & NCT01120288 & I & Completed & Solid tumors \\
\hline & NCT00466583 & I & Completed & Solid tumors/lymphoma \\
\hline \multicolumn{5}{|c|}{ Differentiation inducer } \\
\hline \multirow[t]{4}{*}{ retinoic acid } & NCT01276730 & II & Completed & Cervical cancer \\
\hline & NCT00002586 & II & Completed & Lung cancer \\
\hline & NCT01048645 & II & Completed & Lung cancer \\
\hline & NCT00004149 & II & Completed & Prostate cancer \\
\hline \multirow[t]{2}{*}{ arsenic trioxide } & NCT00128596 & II & Completed & Metastatic liver cancer \\
\hline & NCT00005069 & II & Completed & Metastatic kidney cancer \\
\hline dimethylsulfoxide & NCT04439318 & II & Not yet recruiting & Multiple myeloma \\
\hline
\end{tabular}

\subsection{Targeting Differentiation Mechanisms of CSCS}

CSCs harbor the properties of unlimited self-renewing and multiple directions differentiation, these dedifferentiated properties contribute to the development, recurrence after treatment and MDR of cancer to a large degree. The higher dedifferentiated states of cancer cells were always linked to the poorer prognosis, a contrary result to the differentiated states. As with iPSCs, the source of CSCs could be some stromal cells induced by some reprogramming factors; it was indicated that de-differential states of CRC CSCs derived from stromal fibroblasts could promote chemoresistance in CRC [168]. Thus, inducing cell differentiation from a dedifferentiated state could be a feasible therapy [169] (Figure 4). Inducing differentiation therapy has been proven to be successful in many diseases, including orthopedic treatment, age-related bone loss and some hematological tumors. Many related agents and biological technologies have been proven to be effective in cellular and clinical trials. Sandy Azzi et al. showed that IL15 could induce renal cancer stem cell differentiation and increase sensitivity to chemotherapeutic drugs [170]. Low-intensity ultrasound can modulate cell proliferation and induce cell differentiation; it was potentially shown that the stemness of liver cancer stem cells marked with CD44/CD133 could be impaired by dual-frequency ultrasound with its ability to induce CSC differentiation [171]. Nanomedicine shows faster, more accurate and sensitive characteristics in medicine. A combination of nanoparticle 
engineering and hypothesis-free sensing was proposed to induce CSC differentiation and showed its potential functions in antitumor therapeutics [172]. All-trans retinoic acid (ATRA) is the mesostate of vitamin A, which was known as its promoting differentiation in many disease treatments, especially in malignant tumors [173]. There are also many other differentiation inducers, such as dimethyl sulfoxide and retinal, although there is no clear evidence to support their relationship with CSC, their application has been proven to be valuable in antitumor therapy, inducing CSCs differentiation maybe the potential mechanism, and some of them have been evaluated in many clinical trials (Table 5).

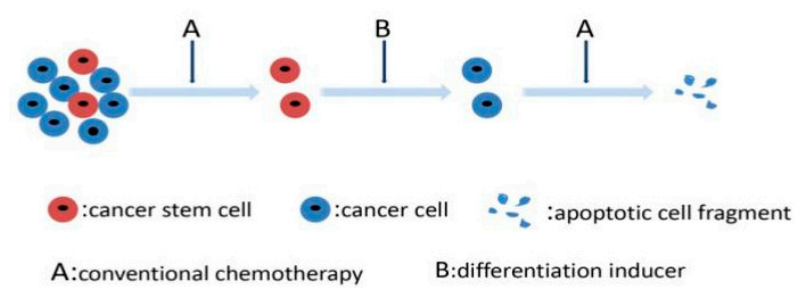

Figure 4. Inducing differentiation therapy to eliminate CSCs.

\subsection{Immunity Method of CSCs}

Tumor immunological therapy has shown a large amount of potential in many cancer types. The mechanism of tumor immunological therapy is to inhibit or eliminate tumor cells by activating the immune system, which includes innate immunity and adaptive immunity. The recent evidence shows that CSCs harbor the capacity of immuno-suppression via several mechanisms; it was revealed that some well-known immunosuppressive molecules, such as PD-L1 and CTLA-4, were higher expressed in CSCs than in common tumor cells [174,175]. Antigen presentation plays a crucial role in cells immunity, it was indicated that CSCs could impair the antigen presentation by downregulating the expression of MHC molecules and some antigen processing molecules, such as transporter associated with antigen processing (TAP) and $\beta$-macroglobulin [176]; researchers also found that the abnormal expression of tumor-associated antigens in CSCs contributed to immune invasion via reducing immunogenicity; CSCs could also promote to build suppressive TME via recruiting some immune cells, such as tumor-associated macrophage (TAM) and regulatory $\mathrm{T}$ cell(Treg), and secreting some immuno-suppressive molecules, such as CD200, TGF- $\beta$ and IFNs, to inhibit CSCs-targeted immune-response [177], Hiroyuki Tsuchiya et al. also summarized that CSC s could impair NK cell function, such as inhibiting the release of cytolytic granules, regulating the expression of the different NK-cell ligands, to escape immune response, they thought the characteristic of immune invasion was a more fundamental feature to CSCs than the tumor-initiating property [178]. It is necessary to find some new strategies to target CSCs via immunity methods. As mentioned before, except for the surface markers, such as CD44, CD133 and ALDH, which could be targeted by some immunological molecules. There are also some other immunological strategies to target CSCs.

\subsubsection{Tumor Vaccine}

The tumor vaccine has shown a large amount of potential and success in recent years; its basic mechanism is to inhibit or eliminate tumor cells by activating the human immune system, which is initiated by the artificial injection of immunogenic tumor antigen. With the increased and deeper research into the tumor vaccine and CSCs, a CSC-based vaccine was proposed to target and eliminate CSCs directly. Lin Lu et al. indicated that CSCs marked by ALDH could be directly targeted by the ALDH CSC-DC vaccine, and also showed its potential function in the adjuvant setting of recurrent tumors [179]. MUC1 was found to participate in regulating the stemness of colorectal stem cells (CCSCs), and the CSC vaccine based on MUC1 has been proven to be effective and safe in inhibiting CCSCs marked by CD133+ via activating humoral immunity [180]. A similar CSC inhibiting effect of the CSC vaccine was also found in melanoma, ovarian cancer, lung cancer, liver cancer and 
nasopharyngeal cancer. CSCs comprise a small percentage of the total tumor tissue, which makes it more difficult to target CSCs by a tumor vaccine. Some combinational strategies have been suggested to target CSCs more efficiently, such as a combination of the CSC vaccine with some conventional chemotherapeutic drugs [181]. In recent years, some CSC vaccines have been evaluated in clinical trials; however, many studies focusing on CSC vaccines were conducted in immunodeficient mice where the immunological environment was significantly different from the normal human body. Thus, more clinical trials are necessary to prove its successful application.

\subsubsection{Chimeric Antigen Receptor T Cell Therapy (CAR-T)}

CAR-T has become popular in target therapy in recent years; T cells can be reprogrammed into CAR-T cells by adding an artificially designed CAR with gene-editing technology, which makes $\mathrm{T}$ cells more accurate and threatening to target tumor cells. To date, there have been five generations of CAR designing. CAR-T first showed its success in the hematological tumor [182]; it has also been found to be effective in many solid tumors, including gastric cancer, pancreatic cancer and breast cancer. Researchers thought it was feasible to inhibit CSCs by CAR-T, some surface markers, such as CD44, CD133 and EpCAM, were used as targets to identify the function of CAR-T in CSC therapy. The efficiency and safety of some CAR-T products have been evaluated in clinical trials. Although CAR-T harbors many advantages in antitumor therapy, there are still many issues, such as the lack of a unique specific target, effective concentration and persistence of CAR-T cells in the targeting area; meanwhile, some adverse reactions, such as off-tumor effects, neurotoxicity, cytokine release syndrome(CRS), soluble tumor syndrome and blood coagulation disorders, which have been mentioned in previous studies $[183,184]$. The majority of CSC-CAR-T studies are preclinical trials, cell experiments and animal experiments; however, more related clinical studies are needed to prove its value via working alone or in combination with tumor target therapy.

\subsubsection{Oncolytic Virus}

The oncolytic virus was designed to damage tumor cells by viruses with low toxicity. Its basic mechanism includes inducing cell lysis via virus proliferation and toxicity of virusrelated proteins, activating non-specific and specific immunity and inhibiting angiogenesis. The first oncolytic virus-related report was the rabies virus, which could inhibit cervical cancer cells. Subsequently, many studies indicated that oncolytic virus therapy showed potential in the anti-tumor field $[185,186]$, including hematological malignancies and some solid tumors. The oncolytic virus was also proven to be efficient in tumor therapy via inhibiting CSCs. As mentioned before, conventional chemotherapeutic drugs showed failure in eliminating CSCs due to several factors, such as quiescent state, anti-apoptotic proteins, ROS level and DNA repairmen. However, the oncolytic virus could induce CSC lysis via infecting both quiescent and dividing cells, this process will not be influenced by these factors [187]. Although the oncolytic virus showed a large amount of potential in inhibiting CSCs, a combined therapy of oncolytic virus with chemotherapy and radiotherapy should be more feasible and efficient in CSC therapy, which has been conducted and proven to be efficient in many cases. In addition, the sensitivity and susceptibility of oncolytic virus to host tumor cells are still core problems in engineering oncolytic virus.

\subsubsection{Targeting CSC-Immune Cell Crosstalk}

As we know, there is a close link between CSC biological characteristics and the immune system. In addition to differentiating into endothelial cells, pericytes and fibroblasts to build CSC niches, CSCs can also build their own TME via regulating various different immune cells and signal pathways, which contributes to tumor immunosuppression and immune escape. According to a recent report, CSCs could recruit tumor-associated macrophages (TAMs) and induce their polarization via different chemokines (IL-4 and IL13) and signal pathways (Wnt, STAT3 and NF-kB). CSCs can promote bone marrow-derived 
macrophage (BMDM) invasion and activation via secreting various soluble cytokines and exosomes, and can also inhibit T-cell functions via secreting TGF- $\beta$, CCL2, TNC, etc. Meanwhile, these immune cells can also regulate CSC stemness via different cytokines. Peiwen Chen et al. highlighted the therapeutic potential of targeting CSC-TAM crosstalk, CSCMDSC crosstalk and CSC-T-cell crosstalk in their study [188]. Karina E Gomez et al. found that TAM could increase hyaluronic acid (HA) and tumor cell invasion, whereas HA could enhance PI3K-4EBP1-SOX2 signaling and CSC fraction in human neck squamous cell carcinoma (HNSCC); they found that it is feasible to inhibit CSCs via targeting CD44 or/and TAM [189]. MDSC contributes to immune suppression. Dongjun Peng et al. revealed that MDSC could enhance CSC stemness and inhibit T-cells activation via the STAT3-NOTCH signal pathway in breast cancer; they found its potential to inhibit CSCs and immune escape via targeting STAT3-NOTCH crosstalk [190]. It was indicated that MDSC could increase CSC stemness and tumor cell PD-L1 expression by the production of PGE2 in epithelial ovarian cancer, and also MDSC might be an effective target to inhibit ovarian tumor cells via reducing ovarian CSC stemness and PD-L1expression [191]; meanwhile, Xiaofeng Li et al. revealed that MDSC could also promote CSC stemness in ovarian cancer via inducing the CSF2/p-STAT3 signaling pathway, and they thought it could enhance the efficacy of conventional treatments by targeting MDSC and colony-stimulating factor 2 (CSF2) [192]. These preclinical studies indicate the therapeutic potential of targeting CSC-immune cells crosstalk in CSC therapy.

To date, many immunity products targeting CSCs have been evaluated in clinical trials (Table 6). There are also some other existing immunity-related methods targeting CSCs, such as immune checkpoint inhibitors (PD-1/PD-L1 inhibitors), immune activators and CAR-NK, which have been mentioned in previous studies. Immunity is the basic mechanism to protect the human body from damage, immunotherapy should be the basic strategy to inhibit CSCs alone or combined.

Table 6. Immunity methods targeting CSCs which have been evaluated in clinical trials.

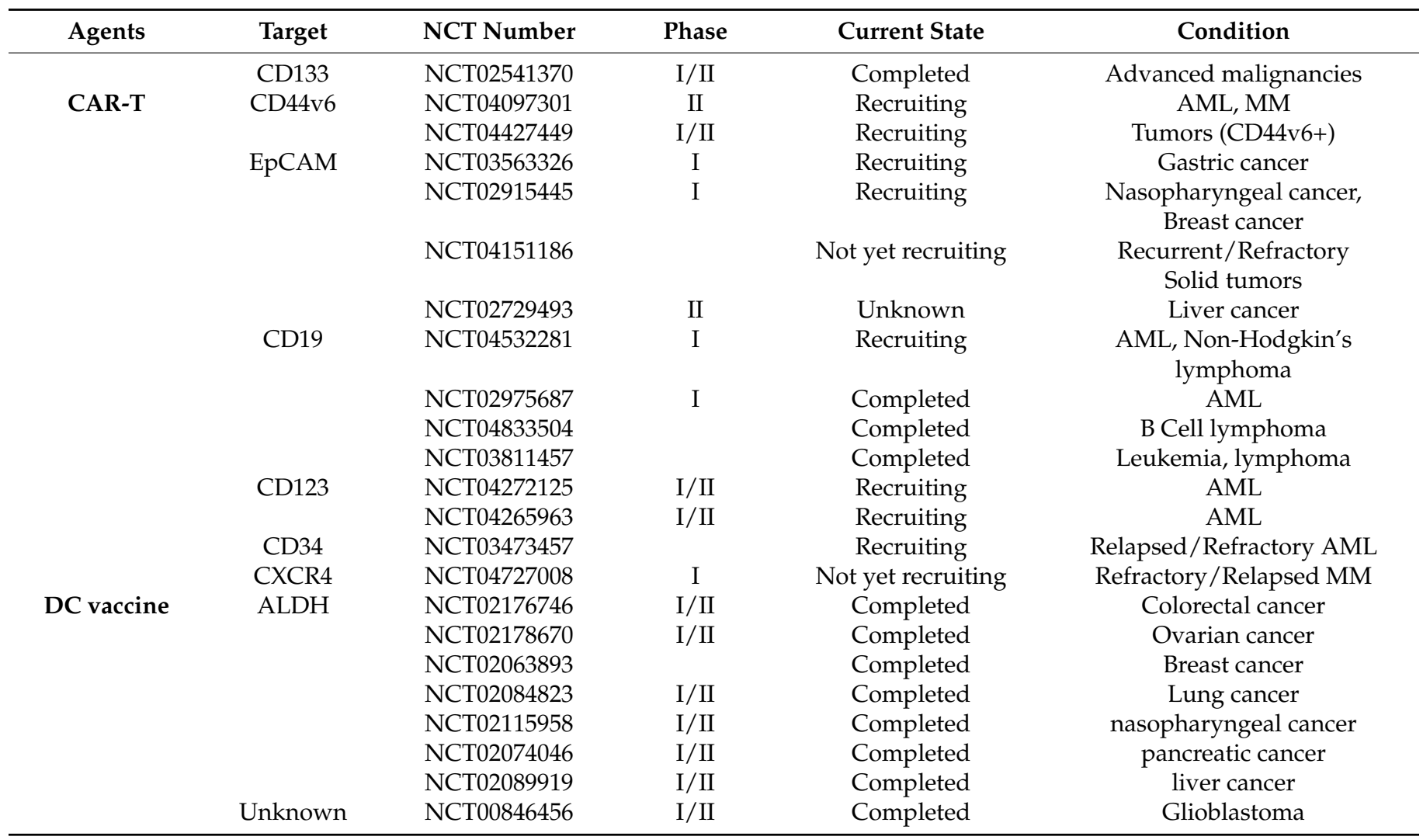




\section{Conclusions}

Obviously, CSCs play a crucial role in the tumorigenesis, development, metastasis and recurrence of tumors. The adaptive mechanism consists of a unique mitosis pattern, unique metabolic phenotype, and CSC niches, which protects CSCs and makes them difficult to eliminate by conventional therapies. According to previous studies, many problems still need to be solved: (1) The lack of strong specificity to target CSCs: CSC comprises a small percentage in total cancer tissues; meanwhile, some of the surface markers detected on CSCs have also been found on normal stem cells, even normal cells, which makes accurate surface maker-targeted therapies more difficult and causes adverse damage to the human body. (2) As with TME in solid tumor cells, CSC niches are a stubborn shield to protect CSCs from human immunity attack, more detailed components of CSC niches and their targeted strategies need to be found to impair CSC niches. (3) CSCs are also tumor cells, many tumor-related signal pathways must contribute to CSCs in some aspects. CSC-related signal pathways work in a complex network, and the unclear synergism or antagonism among different signal pathways makes signal pathway-targeting strategies controversial. The signal pathway is just the route, not the origin; thus, more attention should be paid to find a strategy which could inhibit CSCs at their origin. (4) Most of the products proven their anti-CSCs in vitro experiment where the immunity environment was too simple; therefore, more clinical trials need to be conducted to test the safety and efficacy of anti-CSC-products. Immunotherapy should be considered as the baseline. In various immunotherapies, such as CAR-T, CAR-NK and DC-vaccine, they have shown antitumor potential in recent years. Additionally, nanomedicine provides an accurate route to transport drugs to the targeted areas; a combinational strategy consisting of different drugs that work with different mechanisms may be an ideal option in inhibiting CSCs.

Author Contributions: B.H. prepared the first draft of the review (literature search, tables, figures). X.Y. prepared literature search and provided language assistance. Finally, the manuscript was completed under the guidance and supervision of Y.L. All authors have read and agreed to the published version of the manuscript.

Funding: This work was supported by the National Natural Science Foundation of China (31770537), Special Research Project of Lanzhou University Serving the Economic and Social Development of Gansu Province (054000282).

Acknowledgments: The authors thank Yumin Li for his comments on this manuscript.

Conflicts of Interest: The authors declare no conflict of interest.

\section{References}

1. Siegel, R.L.; Miller, K.D.; Fuchs, H.E.; Jemal, A. Cancer Statistics, 2021. CA Cancer J. Clin. 2021, 71, 7-33. [CrossRef]

2. Heron, M.; Anderson, R.N. Changes in the Leading Cause of Death: Recent Patterns in Heart Disease and Cancer Mortality. NCHS Data Brief 2016, 254, 1-8.

3. Lee, Y.T.; Tan, Y.J.; Oon, C.E. Molecular targeted therapy: Treating cancer with specificity. Eur. J. Pharmacol. 2018, 834, 188-196. [CrossRef] [PubMed]

4. Pan, Y.; Ma, S.; Cao, K.; Zhou, S.; Zhao, A.; Li, M.; Qian, F.; Zhu, C. Therapeutic approaches targeting cancer stem cells. J. Cancer Res. Ther. 2018, 14, 1469-1475. [PubMed]

5. Yang, L.; Shi, P.; Zhao, G.; Xu, J.; Peng, W.; Zhang, J.; Zhang, G.; Wang, X.; Dong, Z.; Chen, F.; et al. Targeting cancer stem cell pathways for cancer therapy. Signal Transduct. Target. Ther. 2020, 5, 8. [CrossRef] [PubMed]

6. Batlle, E.; Clevers, H. Cancer stem cells revisited. Nat. Med. 2017, 23, 1124-1134. [CrossRef]

7. Eun, K.; Ham, S.W.; Kim, H. Cancer stem cell heterogeneity: Origin and new perspectives on CSC targeting. BMB Rep. 2017, 50, 117-125. [CrossRef]

8. Najafi, M.; Mortezaee, K.; Ahadi, R. Cancer stem cell (a)symmetry \& plasticity: Tumorigenesis and therapy relevance. Life Sci. 2019, 231, 116520.

9. Morrison, S.J.; Kimble, J. Asymmetric and symmetric stem-cell divisions in development and cancer. Nature 2006, 441, 1068-1074. [CrossRef] [PubMed]

10. Knoblich, J.A. Mechanisms of asymmetric stem cell division. Cell 2008, 132, 583-597. [CrossRef] 
11. Bai, S.; Ingram, P.; Chen, Y.C.; Deng, N.; Pearson, A.; Niknafs, Y.S.; O'Hayer, P.; Wang, Y.; Zhang, Z.Y.; Boscolo, E.; et al. EGFL6 Regulates the Asymmetric Division, Maintenance, and Metastasis of ALDH+ Ovarian Cancer Cells. Cancer Res. 2016, 76, 6396-6409. [CrossRef] [PubMed]

12. Sonbol, M.B.; Ahn, D.H.; Bekaii-Saab, T. Therapeutic Targeting Strategies of Cancer Stem Cells in Gastrointestinal Malignancies. Biomedicines 2019, 7, 17. [CrossRef]

13. Smith, P.; Azzam, M.; Hinck, L. Extracellular Regulation of the Mitotic Spindle and Fate Determinants Driving Asymmetric Cell Division. Results Probl. Cell Differ. 2017, 61, 351-373. [PubMed]

14. Lathia, J.D.; Hitomi, M.; Gallagher, J.; Gadani, S.P.; Adkins, J.; Vasanji, A.; Liu, L.; Eyler, C.E.; Heddleston, J.M.; Wu, Q.; et al. Distribution of CD133 reveals glioma stem cells self-renew through symmetric and asymmetric cell divisions. Cell Death Dis. 2011, 2, e200. [CrossRef]

15. Kaseb, H.O.; Lewis, D.W.; Saunders, W.S.; Gollin, S.M. Cell division patterns and chromosomal segregation defects in oral cancer stem cells. Genes Chromosomes Cancer 2016, 55, 694-709. [CrossRef] [PubMed]

16. Hitomi, M.; Chumakova, A.P.; Silver, D.J.; Knudsen, A.M.; Pontius, W.D.; Murphy, S.; Anand, N.; Kristensen, B.W.; Lathia, J.D. Asymmetric cell division promotes therapeutic resistance in glioblastoma stem cells. JCI Insight 2021, 6, e130510. [CrossRef]

17. Vander Heiden, M.G.; Cantley, L.C.; Thompson, C.B. Understanding the Warburg effect: The metabolic requirements of cell proliferation. Science 2009, 324, 1029-1033. [CrossRef]

18. Peng, F.; Wang, J.H.; Fan, W.J.; Meng, Y.T.; Li, M.M.; Li, T.T.; Cui, B.; Wang, H.F.; Zhao, Y.; An, F.; et al. Glycolysis gatekeeper PDK1 reprograms breast cancer stem cells under hypoxia. Oncogene 2018, 37, 1062-1074. [CrossRef]

19. Dong, C.; Yuan, T.; Wu, Y.; Wang, Y.; Fan, T.W.; Miriyala, S.; Lin, Y.; Yao, J.; Shi, J.; Kang, T.; et al. Loss of FBP1 by Snail-mediated repression provides metabolic advantages in basal-like breast cancer. Cancer Cell 2013, 23, 316-331. [CrossRef]

20. Farge, T.; Saland, E.; de Toni, F.; Aroua, N.; Hosseini, M.; Perry, R.; Bosc, C.; Sugita, M.; Stuani, L.; Fraisse, M.; et al. ChemotherapyResistant Human Acute Myeloid Leukemia Cells Are Not Enriched for Leukemic Stem Cells but Require Oxidative Metabolism. Cancer Discov. 2017, 7, 716-735. [CrossRef]

21. Lee, K.M.; Giltnane, J.M.; Balko, J.M.; Schwarz, L.J.; Guerrero-Zotano, A.L.; Hutchinson, K.E.; Nixon, M.J.; Estrada, M.V.; Sánchez, V.; Sanders, M.E.; et al. MYC and MCL1 Cooperatively Promote Chemotherapy-Resistant Breast Cancer Stem Cells via Regulation of Mitochondrial Oxidative Phosphorylation. Cell Metab. 2017, 26, 633-647.e7. [CrossRef]

22. Janiszewska, M.; Suvà, M.L.; Riggi, N.; Houtkooper, R.H.; Auwerx, J.; Clément-Schatlo, V.; Radovanovic, I.; Rheinbay, E.; Provero, P.; Stamenkovic, I. Imp2 controls oxidative phosphorylation and is crucial for preserving glioblastoma cancer stem cells. Genes Dev. 2012, 26, 1926-1944. [CrossRef]

23. Gao, C.; Shen, Y.; Jin, F.; Miao, Y.; Qiu, X. Cancer Stem Cells in Small Cell Lung Cancer Cell Line H446: Higher Dependency on Oxidative Phosphorylation and Mitochondrial Substrate-Level Phosphorylation than Non-Stem Cancer Cells. PLoS ONE 2016, 11, e0154576. [CrossRef] [PubMed]

24. Sancho, P.; Burgos-Ramos, E.; Tavera, A.; Bou Kheir, T.; Jagust, P.; Schoenhals, M.; Barneda, D.; Sellers, K.; Campos-Olivas, R.; Graña, O.; et al. MYC/PGC-1 $\alpha$ Balance Determines the Metabolic Phenotype and Plasticity of Pancreatic Cancer Stem Cells. Cell Metab. 2015, 22, 590-605. [CrossRef] [PubMed]

25. Tanabe, A.; Sahara, H. The Metabolic Heterogeneity and Flexibility of Cancer Stem Cells. Cancers 2020, 12, 2780. [CrossRef] [PubMed]

26. Talukdar, S.; Bhoopathi, P.; Emdad, L.; Das, S.; Sarkar, D.; Fisher, P.B. Dormancy and cancer stem cells: An enigma for cancer therapeutic targeting. Adv. Cancer Res. 2019, 141, 43-84. [PubMed]

27. Assaraf, Y.G.; Brozovic, A.; Gonçalves, A.C.; Jurkovicova, D.; Linē, A.; Machuqueiro, M.; Saponara, S.; Sarmento-Ribeiro, A.B.; Xavier, C.P.R.; Vasconcelos, M.H. The multi-factorial nature of clinical multidrug resistance in cancer. Drug Resist. Updates Rev. Comment. Antimicrob. Anticancer Chemother. 2019, 46, 100645. [CrossRef] [PubMed]

28. Zhao, J. Cancer stem cells and chemoresistance: The smartest survives the raid. Pharmacol. Ther. 2016, 160, 145-158. [CrossRef] [PubMed]

29. Abad, E.; Graifer, D.; Lyakhovich, A. DNA damage response and resistance of cancer stem cells. Cancer Lett. 2020, 474, 106-117. [CrossRef]

30. Wang, K.; Zhang, T.; Dong, Q.; Nice, E.C.; Huang, C.; Wei, Y. Redox homeostasis: The linchpin in stem cell self-renewal and differentiation. Cell Death Dis. 2013, 4, e537. [CrossRef]

31. Chen, Z.; Shi, T.; Zhang, L.; Zhu, P.; Deng, M.; Huang, C.; Hu, T.; Jiang, L.; Li, J. Mammalian drug efflux transporters of the ATP binding cassette (ABC) family in multidrug resistance: A review of the past decade. Cancer Lett. 2016, 370, 153-164. [CrossRef]

32. Kazi, J.U. Mechanisms of Anticancer Therapy Resistance: The Role of Cancer Stem Cells. Int. J. Mol. Sci. 2020, 21, 9006. [CrossRef]

33. Hou, H.; Sun, H.; Lu, P.; Ge, C.; Zhang, L.; Li, H.; Zhao, F.; Tian, H.; Zhang, L.; Chen, T.; et al. Tunicamycin potentiates cisplatin anticancer efficacy through the DPAGT1/Akt/ABCG2 pathway in mouse Xenograft models of human hepatocellular carcinoma. Mol. Cancer Ther. 2013, 12, 2874-2884. [CrossRef] [PubMed]

34. Najafi, M.; Mortezaee, K.; Majidpoor, J. Cancer stem cell (CSC) resistance drivers. Life Sci. 2019, 234, 116781. [CrossRef] [PubMed]

35. Shen, S.; Xu, X.; Lin, S.; Zhang, Y.; Liu, H.; Zhang, C.; Mo, R. A nanotherapeutic strategy to overcome chemotherapeutic resistance of cancer stem-like cells. Nat. Nanotechnol. 2021, 16, 104-113. [CrossRef]

36. Nunes, T.; Hamdan, D.; Leboeuf, C.; El Bouchtaoui, M.; Gapihan, G.; Nguyen, T.T.; Meles, S.; Angeli, E.; Ratajczak, P.; Lu, H.; et al. Targeting Cancer Stem Cells to Overcome Chemoresistance. Int. J. Mol. Sci. 2018, 19, 4036. [CrossRef] 
37. Zhou, H.M.; Zhang, J.G.; Zhang, X.; Li, Q. Targeting cancer stem cells for reversing therapy resistance: Mechanism, signaling, and prospective agents. Signal Transduct. Target. Ther. 2021, 6, 62. [CrossRef]

38. Lapidot, T.; Sirard, C.; Vormoor, J.; Murdoch, B.; Hoang, T.; Caceres-Cortes, J.; Minden, M.; Paterson, B.; Caligiuri, M.A.; Dick, J.E. A cell initiating human acute myeloid leukaemia after transplantation into SCID mice. Nature 1994, 367, 645-648. [CrossRef] [PubMed]

39. Yan, Y.; Zuo, X.; Wei, D. Concise Review: Emerging Role of CD44 in Cancer Stem Cells: A Promising Biomarker and Therapeutic Target. Stem Cells Transl. Med. 2015, 4, 1033-1043. [CrossRef]

40. Majeti, R. Monoclonal antibody therapy directed against human acute myeloid leukemia stem cells. Oncogene 2011, 30, 1009-1019. [CrossRef] [PubMed]

41. Buishand, F.O.; Arkesteijn, G.J.; Feenstra, L.R.; Oorsprong, C.W.; Mestemaker, M.; Starke, A.; Speel, E.J.; Kirpensteijn, J.; Mol, J.A. Identification of CD90 as Putative Cancer Stem Cell Marker and Therapeutic Target in Insulinomas. Stem Cells Dev. 2016, 25, 826-835. [CrossRef]

42. Koyama, S.; Tsuchiya, H.; Amisaki, M.; Sakaguchi, H.; Honjo, S.; Fujiwara, Y.; Shiota, G. NEAT1 is Required for the Expression of the Liver Cancer Stem Cell Marker CD44. Int. J. Mol. Sci. 2020, 21, 1927. [CrossRef]

43. Takaishi, S.; Okumura, T.; Tu, S.; Wang, S.S.; Shibata, W.; Vigneshwaran, R.; Gordon, S.A.; Shimada, Y.; Wang, T.C. Identification of gastric cancer stem cells using the cell surface marker CD44. Stem Cells 2009, 27, 1006-1020. [CrossRef] [PubMed]

44. Zhang, H.; Brown, R.L.; Wei, Y.; Zhao, P.; Liu, S.; Liu, X.; Deng, Y.; Hu, X.; Zhang, J.; Gao, X.D.; et al. CD44 splice isoform switching determines breast cancer stem cell state. Genes Dev. 2019, 33, 166-179. [CrossRef] [PubMed]

45. Lee, C.J.; Dosch, J.; Simeone, D.M. Pancreatic cancer stem cells. J. Clin. Oncol. Off. J. Am. Soc. Clin. Oncol. 2008, 26, 2806-2812. [CrossRef] [PubMed]

46. Rivas, S.; Antón, I.M.; Wandosell, F. WIP-YAP/TAZ as A New Pro-Oncogenic Pathway in Glioma. Cancers 2018, 10, 191. [CrossRef]

47. Li, X.; Ma, X.; Chen, L.; Gu, L.; Zhang, Y.; Zhang, F.; Ouyang, Y.; Gao, Y.; Huang, Q.; Zhang, X. Prognostic value of CD44 expression in renal cell carcinoma: A systematic review and meta-analysis. Sci. Rep. 2015, 5, 13157. [CrossRef]

48. Wang, C.; Xie, J.; Guo, J.; Manning, H.C.; Gore, J.C.; Guo, N. Evaluation of CD44 and CD133 as cancer stem cell markers for colorectal cancer. Oncol. Rep. 2012, 28, 1301-1308. [CrossRef]

49. Geng, S.; Guo, Y.; Wang, Q.; Li, L.; Wang, J. Cancer stem-like cells enriched with CD29 and CD44 markers exhibit molecular characteristics with epithelial-mesenchymal transition in squamous cell carcinoma. Arch. Dermatol. Res. 2013, 305, 35-47. [CrossRef]

50. Sharma, R.B.; Wang, Q.; Khillan, J.S. Amplification of tumor inducing putative cancer stem cells (CSCs) by vitamin A/retinol from mammary tumors. Biochem. Biophys. Res. Commun. 2013, 436, 625-631. [CrossRef]

51. Fang, D.D.; Kim, Y.J.; Lee, C.N.; Aggarwal, S.; McKinnon, K.; Mesmer, D.; Norton, J.; Birse, C.E.; He, T.; Ruben, S.M.; et al. Expansion of CD133(+) colon cancer cultures retaining stem cell properties to enable cancer stem cell target discovery. Br. J. Cancer 2010, 102, 1265-1275. [CrossRef]

52. Li, C.; Liu, S.; Yan, R.; Han, N.; Wong, K.K.; Li, L. CD54-NOTCH1 axis controls tumor initiation and cancer stem cell functions in human prostate cancer. Theranostics 2017, 7, 67-80. [CrossRef] [PubMed]

53. Li, M.; Knight, D.A.; Smyth, M.J.; Stewart, T.J. Sensitivity of a novel model of mammary cancer stem cell-like cells to TNF-related death pathways. Cancer Immunol. Immunother. 2012, 61, 1255-1268. [CrossRef] [PubMed]

54. Sugita, M.; Guzman, M.L. CD123 as a Therapeutic Target Against Malignant Stem Cells. Hematol./Oncol. Clin. N. Am. 2020, 34, 553-564. [CrossRef] [PubMed]

55. Nishikawa, S.; Konno, M.; Hamabe, A.; Hasegawa, S.; Kano, Y.; Ohta, K.; Fukusumi, T.; Sakai, D.; Kudo, T.; Haraguchi, N.; et al. Aldehyde dehydrogenase high gastric cancer stem cells are resistant to chemotherapy. Int. J. Oncol. 2013, 42, 1437-1442. [CrossRef] [PubMed]

56. Chen, L.; Long, C.; Tran, K.A.M.; Lee, J. A Synthetic Binder of Breast Cancer Stem Cells. Chemistry 2018, 24, 3694-3698. [CrossRef]

57. Ishiwata, T.; Matsuda, Y.; Yoshimura, H.; Sasaki, N.; Ishiwata, S.; Ishikawa, N.; Takubo, K.; Arai, T.; Aida, J. Pancreatic cancer stem cells: Features and detection methods. Pathol. Oncol. Res. 2018, 24, 797-805. [CrossRef]

58. Wang, L.; Park, P.; La Marca, F.; Than, K.D.; Lin, C.Y. BMP-2 inhibits tumor-initiating ability in human renal cancer stem cells and induces bone formation. J. Cancer Res. Clin. Oncol. 2015, 141, 1013-1024. [CrossRef]

59. Giraud, J.; Failla, L.M.; Pascussi, J.M.; Lagerqvist, E.L.; Ollier, J.; Finetti, P.; Bertucci, F.; Ya, C.; Gasmi, I.; Bourgaux, J.F.; et al. Autocrine Secretion of Progastrin Promotes the Survival and Self-Renewal of Colon Cancer Stem-like Cells. Cancer Res. 2016, 76, 3618-3628. [CrossRef]

60. Prince, M.E.P.; Zhou, L.; Moyer, J.S.; Tao, H.; Lu, L.; Owen, J.; Etigen, M.; Zheng, F.; Chang, A.E.; Xia, J.; et al. Evaluation of the immunogenicity of ALDH(high) human head and neck squamous cell carcinoma cancer stem cells in vitro. Oral Oncol. 2016, 59, 30-42. [CrossRef]

61. Katsuta, E.; Tanaka, S.; Mogushi, K.; Shimada, S.; Akiyama, Y.; Aihara, A.; Matsumura, S.; Mitsunori, Y.; Ban, D.; Ochiai, T.; et al. CD73 as a therapeutic target for pancreatic neuroendocrine tumor stem cells. Int. J. Oncol. 2016, 48, 657-669. [CrossRef]

62. Khan, A.I.; Kerfoot, S.M.; Heit, B.; Liu, L.; Andonegui, G.; Ruffell, B.; Johnson, P.; Kubes, P. Role of CD44 and hyaluronan in neutrophil recruitment. J. Immunol. 2004, 173, 7594-7601. [CrossRef] [PubMed]

63. Flynn, K.M.; Michaud, M.; Canosa, S.; Madri, J.A. CD44 regulates vascular endothelial barrier integrity via a PECAM-1 dependent mechanism. Angiogenesis 2013, 16, 689-705. [CrossRef] [PubMed] 
64. Zhu, S.N.; Nölle, B.; Duncker, G. Expression of adhesion molecule CD44 on human corneas. Br. J. Ophthalmol. 1997, 81, 80-84. [CrossRef] [PubMed]

65. Girgrah, N.; Letarte, M.; Becker, L.E.; Cruz, T.F.; Theriault, E.; Moscarello, M.A. Localization of the CD44 glycoprotein to fibrous astrocytes in normal white matter and to reactive astrocytes in active lesions in multiple sclerosis. J. Neuropathol. Exp. Neurol. 1991, 50, 779-792. [CrossRef] [PubMed]

66. Zhu, W.; Li, S.; Zou, B.; Liu, H.; Wang, S. Expressions and clinical significance of HER4 and CD44 in sinonasal mucosal malignant melanoma. Melanoma Res. 2018, 28, 105-110. [CrossRef]

67. Reid, S.D.; Pockley, A.G. Cytokine regulation of CD44 expression on rat intestinal epithelial cells. Immunol. Investig. 2000, 29, 271-286. [CrossRef]

68. Malan, D.; Wenzel, D.; Schmidt, A.; Geisen, C.; Raible, A.; Bölck, B.; Fleischmann, B.K.; Bloch, W. Endothelial beta1 integrins regulate sprouting and network formation during vascular development. Development 2010, 137, 993-1002. [CrossRef]

69. Togarrati, P.P.; Dinglasan, N.; Desai, S.; Ryan, W.R.; Muench, M.O. CD29 is highly expressed on epithelial, myoepithelial, and mesenchymal stromal cells of human salivary glands. Oral Dis. 2018, 24, 561-572. [CrossRef]

70. Kurata, R.; Futaki, S.; Nakano, I.; Tanemura, A.; Murota, H.; Katayama, I.; Sekiguchi, K. Isolation and characterization of sweat gland myoepithelial cells from human skin. Cell Struct. Funct. 2014, 39, 101-112. [CrossRef]

71. Zhang, M.; Che, Y.; Zhao, S.; Xia, X.; Liu, H.; Liu, J.; Wang, Y.; Han, W.; Yang, Y.; Zhou, C.; et al. TGF- $\beta 1$ promoted the infection of bovine mammary epithelial cells by Staphylococcus aureus through increasing expression of cells' fibronectin and integrin $\beta 1$. Vet. Microbiol. 2019, 237, 108420. [CrossRef]

72. Maio, M.; Del Vecchio, L. Expression and functional role of CD54/Intercellular Adhesion Molecule-1 (ICAM-1) on human blood cells. Leuk. Lymphoma 1992, 8, 23-33. [CrossRef]

73. Takashi, S.; Okubo, Y.; Horie, S. Contribution of CD54 to human eosinophil and neutrophil superoxide production. J. Appl. Physiol. 2001, 91, 613-622. [CrossRef]

74. Morikawa, Y.; Tohya, K.; Hara, T.; Kitamura, T.; Miyajima, A. Expression of IL-3 receptor in testis. Biochem. Biophys. Res. Commun. 1996, 226, 107-112. [CrossRef] [PubMed]

75. Chritton, S.L.; Sheng, M. CYRL, a novel cytokine receptor-like protein expressed in testis, lung, and spleen. Biochem. Biophys. Res. Commun. 2000, 267, 697-702. [CrossRef]

76. Han, X.; Jorgensen, J.L.; Brahmandam, A.; Schlette, E.; Huh, Y.O.; Shi, Y.; Awagu, S.; Chen, W. Immunophenotypic study of basophils by multiparameter flow cytometry. Arch. Pathol. Lab. Med. 2008, 132, 813-819. [CrossRef] [PubMed]

77. Ginestier, C.; Hur, M.H.; Charafe-Jauffret, E.; Monville, F.; Dutcher, J.; Brown, M.; Jacquemier, J.; Viens, P.; Kleer, C.G.; Liu, S.; et al ALDH1 is a marker of normal and malignant human mammary stem cells and a predictor of poor clinical outcome. Cell Stem Cell 2007, 1, 555-567. [CrossRef] [PubMed]

78. Lindgren, D.; Boström, A.K.; Nilsson, K.; Hansson, J.; Sjölund, J.; Möller, C.; Jirström, K.; Nilsson, E.; Landberg, G.; Axelson, H.; et al. Isolation and characterization of progenitor-like cells from human renal proximal tubules. Am. J. Pathol. 2011, 178, 828-837. [CrossRef]

79. Eichin, D.; Pessia, A.; Takeda, A.; Laakkonen, J.; Bellmann, L.; Kankainen, M.; Imhof, B.A.; Stoitzner, P.; Tang, J.; Salmi, M.; et al. CD73 contributes to anti-inflammatory properties of afferent lymphatic endothelial cells in humans and mice. Eur. J. Immunol. 2021, 51, 231-246. [CrossRef] [PubMed]

80. Fuentes, E.; Palomo, I. Extracellular ATP metabolism on vascular endothelial cells: A pathway with pro-thrombotic and anti-thrombotic molecules. Vasc. Pharmacol. 2015, 75, 1-6. [CrossRef]

81. Vermeulen, L.; De Sousa, E.M.F.; van der Heijden, M.; Cameron, K.; de Jong, J.H.; Borovski, T.; Tuynman, J.B.; Todaro, M.; Merz, C.; Rodermond, H.; et al. Wnt activity defines colon cancer stem cells and is regulated by the microenvironment. Nat. Cell Biol. 2010, 12, 468-476. [CrossRef]

82. Ordóñez-Morán, P.; Dafflon, C.; Imajo, M.; Nishida, E.; Huelsken, J. HOXA5 Counteracts Stem Cell Traits by Inhibiting Wnt Signaling in Colorectal Cancer. Cancer Cell 2015, 28, 815-829. [CrossRef]

83. Fendler, A.; Bauer, D.; Busch, J.; Jung, K.; Wulf-Goldenberg, A.; Kunz, S.; Song, K.; Myszczyszyn, A.; Elezkurtaj, S.; Erguen, B.; et al. Inhibiting WNT and NOTCH in renal cancer stem cells and the implications for human patients. Nat. Commun. 2020, 11, 929. [CrossRef]

84. Zhou, M.; Hou, Y.; Yang, G.; Zhang, H.; Tu, G.; Du, Y.E.; Wen, S.; Xu, L.; Tang, X.; Tang, S.; et al. LncRNA-Hh Strengthen Cancer Stem Cells Generation in Twist-Positive Breast Cancer via Activation of Hedgehog Signaling Pathway. Stem Cells 2016, 34, 55-66. [CrossRef]

85. Li, J.; Condello, S.; Thomes-Pepin, J.; Ma, X.; Xia, Y.; Hurley, T.D.; Matei, D.; Cheng, J.X. Lipid Desaturation Is a Metabolic Marker and Therapeutic Target of Ovarian Cancer Stem Cells. Cell Stem Cell 2017, 20, 303-314.e5. [CrossRef]

86. Park, S.Y.; Lee, C.J.; Choi, J.H.; Kim, J.H.; Kim, J.W.; Kim, J.Y.; Nam, J.S. The JAK2/STAT3/CCND2 Axis promotes colorectal Cancer stem cell persistence and radioresistance. J. Exp. Clin. Cancer Res. CR 2019, 38, 399. [CrossRef] [PubMed]

87. Bhola, N.E.; Balko, J.M.; Dugger, T.C.; Kuba, M.G.; Sánchez, V.; Sanders, M.; Stanford, J.; Cook, R.S.; Arteaga, C.L. TGF- $\beta$ inhibition enhances chemotherapy action against triple-negative breast cancer. J. Clin. Investig. 2013, 123, 1348-1358. [CrossRef]

88. Moon, C.M.; Kwon, J.H.; Kim, J.S.; Oh, S.H.; Jin Lee, K.; Park, J.J.; Pil Hong, S.; Cheon, J.H.; Kim, T.I.; Kim, W.H. Nonsteroidal anti-inflammatory drugs suppress cancer stem cells via inhibiting PTGS2 (cyclooxygenase 2) and NOTCH/HES1 and activating PPARG in colorectal cancer. Int. J. Cancer 2014, 134, 519-529. [CrossRef] [PubMed] 
89. Hashemi Goradel, N.; Najafi, M.; Salehi, E.; Farhood, B.; Mortezaee, K. Cyclooxygenase-2 in cancer: A review. J. Cell. Physiol. 2019, 234, 5683-5699. [CrossRef] [PubMed]

90. Leon, G.; MacDonagh, L.; Finn, S.P.; Cuffe, S.; Barr, M.P. Cancer stem cells in drug resistant lung cancer: Targeting cell surface markers and signaling pathways. Pharmacol. Ther. 2016, 158, 71-90. [CrossRef] [PubMed]

91. Wang, K.; Zhang, Q.; Li, D.; Ching, K.; Zhang, C.; Zheng, X.; Ozeck, M.; Shi, S.; Li, X.; Wang, H.; et al. PEST domain mutations in Notch receptors comprise an oncogenic driver segment in triple-negative breast cancer sensitive to a $\gamma$-secretase inhibitor. Clin. Cancer Res. Off. J. Am. Assoc. Cancer Res. 2015, 21, 1487-1496. [CrossRef]

92. Stoeck, A.; Lejnine, S.; Truong, A.; Pan, L.; Wang, H.; Zang, C.; Yuan, J.; Ware, C.; MacLean, J.; Garrett-Engele, P.W.; et al. Discovery of biomarkers predictive of GSI response in triple-negative breast cancer and adenoid cystic carcinoma. Cancer Discov. 2014, 4, 1154-1167. [CrossRef] [PubMed]

93. Miyamoto, S.; Nakanishi, M.; Rosenberg, D.W. Suppression of colon carcinogenesis by targeting Notch signaling. Carcinogenesis 2013, 34, 2415-2423. [CrossRef] [PubMed]

94. Lee, S.M.; Moon, J.; Redman, B.G.; Chidiac, T.; Flaherty, L.E.; Zha, Y.; Othus, M.; Ribas, A.; Sondak, V.K.; Gajewski, T.F.; et al. Phase 2 study of RO4929097, a gamma-secretase inhibitor, in metastatic melanoma: SWOG 0933. Cancer 2015, 121, 432-440. [CrossRef]

95. Strosberg, J.R.; Yeatman, T.; Weber, J.; Coppola, D.; Schell, M.J.; Han, G.; Almhanna, K.; Kim, R.; Valone, T.; Jump, H.; et al. A phase II study of RO4929097 in metastatic colorectal cancer. Eur. J. Cancer 2012, 48, 997-1003. [CrossRef]

96. Diaz-Padilla, I.; Wilson, M.K.; Clarke, B.A.; Hirte, H.W.; Welch, S.A.; Mackay, H.J.; Biagi, J.J.; Reedijk, M.; Weberpals, J.I.; Fleming, G.F.; et al. A phase II study of single-agent RO4929097, a gamma-secretase inhibitor of Notch signaling, in patients with recurrent platinum-resistant epithelial ovarian cancer: A study of the Princess Margaret, Chicago and California phase II consortia. Gynecol. Oncol. 2015, 137, 216-222. [CrossRef]

97. Diaz-Padilla, I.; Hirte, H.; Oza, A.M.; Clarke, B.A.; Cohen, B.; Reedjik, M.; Zhang, T.; Kamel-Reid, S.; Ivy, S.P.; Hotte, S.J.; et al. A phase Ib combination study of RO4929097, a gamma-secretase inhibitor, and temsirolimus in patients with advanced solid tumors. Investig. New Drugs 2013, 31, 1182-1191. [CrossRef] [PubMed]

98. Pandya, K.; Meeke, K.; Clementz, A.G.; Rogowski, A.; Roberts, J.; Miele, L.; Albain, K.S.; Osipo, C. Targeting both Notch and ErbB-2 signalling pathways is required for prevention of ErbB-2-positive breast tumour recurrence. Br. J. Cancer 2011, 105, 796-806. [CrossRef] [PubMed]

99. Aleksic, T.; Feller, S.M. Gamma-secretase inhibition combined with platinum compounds enhances cell death in a large subset of colorectal cancer cells. Cell Commun. Signal. 2008, 6, 8. [CrossRef] [PubMed]

100. Noguera-Troise, I.; Daly, C.; Papadopoulos, N.J.; Coetzee, S.; Boland, P.; Gale, N.W.; Lin, H.C.; Yancopoulos, G.D.; Thurston, G. Blockade of Dll4 inhibits tumour growth by promoting non-productive angiogenesis. Nature 2006, 444, 1032-1037. [CrossRef] [PubMed]

101. Thurston, G.; Noguera-Troise, I.; Yancopoulos, G.D. The Delta paradox: DLL4 blockade leads to more tumour vessels but less tumour growth. Nat. Rev. Cancer 2007, 7, 327-331. [CrossRef]

102. Kuhnert, F.; Chen, G.; Coetzee, S.; Thambi, N.; Hickey, C.; Shan, J.; Kovalenko, P.; Noguera-Troise, I.; Smith, E.; Fairhurst, J.; et al. Dll4 Blockade in Stromal Cells Mediates Antitumor Effects in Preclinical Models of Ovarian Cancer. Cancer Res. 2015, 75, 4086-4096. [CrossRef]

103. Chiorean, E.G.; LoRusso, P.; Strother, R.M.; Diamond, J.R.; Younger, A.; Messersmith, W.A.; Adriaens, L.; Liu, L.; Kao, R.J.; DiCioccio, A.T.; et al. A Phase I First-in-Human Study of Enoticumab (REGN421), a Fully Human Delta-like Ligand 4 (Dll4) Monoclonal Antibody in Patients with Advanced Solid Tumors. Clin. Cancer Res. Off. J. Am. Assoc. Cancer Res. 2015, 21, 2695-2703. [CrossRef] [PubMed]

104. Hoey, T.; Yen, W.C.; Axelrod, F.; Basi, J.; Donigian, L.; Dylla, S.; Fitch-Bruhns, M.; Lazetic, S.; Park, I.K.; Sato, A.; et al. DLL4 blockade inhibits tumor growth and reduces tumor-initiating cell frequency. Cell Stem Cell 2009, 5, 168-177. [CrossRef] [PubMed]

105. Liu, S.; Li, C.; Xin, P.; Zheng, Y.; Peng, Q.; Xu, Y.; Luo, Y.; Wu, Y.; Zhu, X. Sonidegib, a Smoothened Inhibitor, Promotes Apoptosis and Suppresses Proliferation of Natural Killer/T-Cell Lymphoma. Med. Sci. Monit. Int. Med. J. Exp. Clin. Res. 2019, 25, 8579-8586. [CrossRef]

106. Martinelli, G.; Oehler, V.G.; Papayannidis, C.; Courtney, R.; Shaik, M.N.; Zhang, X.; O'Connell, A.; McLachlan, K.R.; Zheng, X.; Radich, J.; et al. Treatment with PF-04449913, an oral smoothened antagonist, in patients with myeloid malignancies: A phase 1 safety and pharmacokinetics study. Lancet Haematol. 2015, 2, e339-e346. [CrossRef]

107. Shaik, N.; Hee, B.; Liang, Y.; LaBadie, R.R. Absolute Oral Bioavailability of Glasdegib (PF-04449913), a Smoothened Inhibitor, in Randomized Healthy Volunteers. Clin. Pharmacol. Drug Dev. 2019, 8, 895-902. [CrossRef] [PubMed]

108. AlMuraikhi, N.; Almasoud, N.; Binhamdan, S.; Younis, G.; Ali, D.; Manikandan, M.; Vishnubalaji, R.; Atteya, M.; Siyal, A.; Alfayez, M.; et al. Hedgehog Signaling Inhibition by Smoothened Antagonist BMS-833923 Reduces Osteoblast Differentiation and Ectopic Bone Formation of Human Skeletal (Mesenchymal) Stem Cells. Stem Cells Int. 2019, 2019, 3435901. [CrossRef]

109. Wu, C.; Hu, S.; Cheng, J.; Wang, G.; Tao, K. Smoothened antagonist GDC-0449 (Vismodegib) inhibits proliferation and triggers apoptosis in colon cancer cell lines. Exp. Ther. Med. 2017, 13, 2529-2536. [CrossRef]

110. Riedlinger, D.; Bahra, M.; Boas-Knoop, S.; Lippert, S.; Bradtmöller, M.; Guse, K.; Seehofer, D.; Bova, R.; Sauer, I.M.; Neuhaus, P.; et al. Hedgehog pathway as a potential treatment target in human cholangiocarcinoma. J. Hepato-Biliary-Pancreat. Sci. 2014, 21, 607-615. [CrossRef] 
111. Lauth, M.; Bergström, A.; Shimokawa, T.; Toftgård, R. Inhibition of GLI-mediated transcription and tumor cell growth by small-molecule antagonists. Proc. Natl. Acad. Sci. USA 2007, 104, 8455-8460. [CrossRef]

112. Hou, X.; Chen, X.; Zhang, P.; Fan, Y.; Ma, A.; Pang, T.; Song, Z.; Jin, Y.; Hao, W.; Liu, F.; et al. Inhibition of hedgehog signaling by GANT58 induces apoptosis and shows synergistic antitumor activity with AKT inhibitor in acute T cell leukemia cells. Biochimie 2014, 101, 50-59. [CrossRef] [PubMed]

113. Zhang, Z.; Hao, C.; Zhang, R.; Pei, X.; Li, J.; Wang, L. A Gli inhibitor GANT61 suppresses cell proliferation, promotes cell apoptosis and induces $\mathrm{G1} / \mathrm{G} 0$ cycle retardation with a dose- and time-dependent manner through inhibiting Notch pathway in multiple myeloma. Cell Cycle 2020, 19, 2063-2073. [CrossRef] [PubMed]

114. Li, J.; Cai, J.; Zhao, S.; Yao, K.; Sun, Y.; Li, Y.; Chen, L.; Li, R.; Zhai, X.; Zhang, J.; et al. GANT61, a GLI inhibitor, sensitizes glioma cells to the temozolomide treatment. J. Exp. Clin. Cancer Res. CR 2016, 35, 184. [CrossRef]

115. Beauchamp, E.M.; Ringer, L.; Bulut, G.; Sajwan, K.P.; Hall, M.D.; Lee, Y.C.; Peaceman, D.; Ozdemirli, M.; Rodriguez, O.; Macdonald, T.J.; et al. Arsenic trioxide inhibits human cancer cell growth and tumor development in mice by blocking Hedgehog/GLI pathway. J. Clin. Investig. 2011, 121, 148-160. [CrossRef] [PubMed]

116. Rimkus, T.K.; Carpenter, R.L.; Qasem, S.; Chan, M.; Lo, H.W. Targeting the Sonic Hedgehog Signaling Pathway: Review of Smoothened and GLI Inhibitors. Cancers 2016, 8, 22. [CrossRef] [PubMed]

117. El-Sahli, S.; Xie, Y.; Wang, L.; Liu, S. Wnt Signaling in Cancer Metabolism and Immunity. Cancers 2019, 11, 904. [CrossRef] [PubMed]

118. Cruciat, C.M.; Niehrs, C. Secreted and transmembrane wnt inhibitors and activators. Cold Spring Harb. Perspect. Biol. 2013, 5 , a015081. [CrossRef]

119. Shao, Y.C.; Wei, Y.; Liu, J.F.; Xu, X.Y. The role of Dickkopf family in cancers: From Bench to Bedside. Am. J. Cancer Res. 2017, 7, 1754-1768.

120. Liang, C.J.; Wang, Z.W.; Chang, Y.W.; Lee, K.C.; Lin, W.H.; Lee, J.L. SFRPs Are Biphasic Modulators of Wnt-Signaling-Elicited Cancer Stem Cell Properties beyond Extracellular Control. Cell Rep. 2019, 28, 1511-1525.e5. [CrossRef]

121. Xavier, C.P.; Melikova, M.; Chuman, Y.; Üren, A.; Baljinnyam, B.; Rubin, J.S. Secreted Frizzled-related protein potentiation versus inhibition of Wnt3a/ $\beta$-catenin signaling. Cell. Signal. 2014, 26, 94-101. [CrossRef]

122. Chen, C.C.; Chen, H.Y.; Su, K.Y.; Hong, Q.S.; Yan, B.S.; Chen, C.H.; Pan, S.H.; Chang, Y.L.; Wang, C.J.; Hung, P.F.; et al. Shisa3 is associated with prolonged survival through promoting $\beta$-catenin degradation in lung cancer. Am. J. Respir. Crit. Care Med. 2014, 190, 433-444. [CrossRef]

123. Maffei, R.; Fiorcari, S.; Martinelli, S.; Benatti, S.; Bulgarelli, J.; Rizzotto, L.; Debbia, G.; Santachiara, R.; Rigolin, G.M.; Forconi, F.; et al. Increased SHISA3 expression characterizes chronic lymphocytic leukemia patients sensitive to lenalidomide. Leuk. Lymphoma 2018, 59, 423-433. [CrossRef] [PubMed]

124. Huynh, L.K.; Hipolito, C.J.; Ten Dijke, P. A Perspective on the Development of TGF- $\beta$ Inhibitors for Cancer Treatment. Biomolecules 2019, 9, 743. [CrossRef] [PubMed]

125. Bose, S.; Banerjee, S.; Mondal, A.; Chakraborty, U.; Pumarol, J.; Croley, C.R.; Bishayee, A. Targeting the JAK/STAT Signaling Pathway Using Phytocompounds for Cancer Prevention and Therapy. Cells 2020, 9, 1451. [CrossRef] [PubMed]

126. Alzahrani, A.S. PI3K/Akt/mTOR inhibitors in cancer: At the bench and bedside. Semin. Cancer Biol. 2019, 59, 125-132. [CrossRef]

127. Jiao, X.X.; Lin, S.Y.; Lian, S.X.; Qiu, Y.R.; Li, Z.H.; Chen, Z.H.; Lu, W.Q.; Zhang, Y.; Deng, L.; Jiang, Y.; et al. The inhibition of the breast cancer by PPAR $\gamma$ agonist pioglitazone through JAK2/STAT3 pathway. Neoplasma 2020, 67, 834-842. [CrossRef]

128. Cai, X.; Yao, Z.; Li, L.; Huang, J. Role of DKK4 in Tumorigenesis and Tumor Progression. Int. J. Biol. Sci. 2018, 14, 616-621. [CrossRef]

129. Courtois, S.; Durán, R.V.; Giraud, J.; Sifré, E.; Izotte, J.; Mégraud, F.; Lehours, P.; Varon, C.; Bessède, E. Metformin targets gastric cancer stem cells. Eur. J. Cancer 2017, 84, 193-201. [CrossRef]

130. Kim, J.H.; Lee, K.J.; Seo, Y.; Kwon, J.H.; Yoon, J.P.; Kang, J.Y.; Lee, H.J.; Park, S.J.; Hong, S.P.; Cheon, J.H.; et al. Effects of metformin on colorectal cancer stem cells depend on alterations in glutamine metabolism. Sci. Rep. 2018, 8, 409. [CrossRef]

131. Shank, J.J.; Yang, K.; Ghannam, J.; Cabrera, L.; Johnston, C.J.; Reynolds, R.K.; Buckanovich, R.J. Metformin targets ovarian cancer stem cells in vitro and in vivo. Gynecol. Oncol. 2012, 127, 390-397. [CrossRef] [PubMed]

132. Mayer, M.J.; Klotz, L.H.; Venkateswaran, V. Metformin and prostate cancer stem cells: A novel therapeutic target. Prostate Cancer Prostatic Dis. 2015, 18, 303-309. [CrossRef] [PubMed]

133. Wheaton, W.W.; Weinberg, S.E.; Hamanaka, R.B.; Soberanes, S.; Sullivan, L.B.; Anso, E.; Glasauer, A.; Dufour, E.; Mutlu, G.M.; Budigner, G.S.; et al. Metformin inhibits mitochondrial complex I of cancer cells to reduce tumorigenesis. eLife 2014, 3 , e02242. [CrossRef] [PubMed]

134. Wang, Z.; Zhou, L.; Xiong, Y.; Yu, S.; Li, H.; Fan, J.; Li, F.; Su, Z.; Song, J.; Sun, Q.; et al. Salinomycin exerts anti-colorectal cancer activity by targeting the $\beta$-catenin/T-cell factor complex. Br. J. Pharmacol. 2019, 176, 3390-3406. [CrossRef]

135. Managò, A.; Leanza, L.; Carraretto, L.; Sassi, N.; Grancara, S.; Quintana-Cabrera, R.; Trimarco, V.; Toninello, A.; Scorrano, L.; Trentin, L.; et al. Early effects of the antineoplastic agent salinomycin on mitochondrial function. Cell Death Dis. 2015, 6, e1930. [CrossRef]

136. Mitani, M.; Yamanishi, T.; Miyazaki, Y.; Otake, N. Salinomycin effects on mitochondrial ion translocation and respiration. Antimicrob. Agents Chemother. 1976, 9, 655-660. [CrossRef]

137. Guo, F.; Yang, Z.; Kulbe, H.; Albers, A.E.; Sehouli, J.; Kaufmann, A.M. Inhibitory effect on ovarian cancer ALDH+ stem-like cells by Disulfiram and Copper treatment through ALDH and ROS modulation. Biomed. Pharmacother. Biomed. Pharmacother. 2019, 118, 109371. [CrossRef] 
138. Eskandari, A.; Suntharalingam, K. A reactive oxygen species-generating, cancer stem cell-potent manganese(ii) complex and its encapsulation into polymeric nanoparticles. Chem. Sci. 2019, 10, 7792-7800. [CrossRef]

139. Han, S.; Wei, R.; Zhang, X.; Jiang, N.; Fan, M.; Huang, J.H.; Xie, B.; Zhang, L.; Miao, W.; Butler, A.C.; et al. CPT1A/2-Mediated FAO Enhancement-A Metabolic Target in Radioresistant Breast Cancer. Front. Oncol. 2019, 9, 1201. [CrossRef]

140. Cheng, S.; Wang, G.; Wang, Y.; Cai, L.; Qian, K.; Ju, L.; Liu, X.; Xiao, Y.; Wang, X. Fatty acid oxidation inhibitor etomoxir suppresses tumor progression and induces cell cycle arrest via PPAR $\gamma$-mediated pathway in bladder cancer. Clin. Sci. 2019, 133, 1745-1758. [CrossRef]

141. Tan, Z.; Xiao, L.; Tang, M.; Bai, F.; Li, J.; Li, L.; Shi, F.; Li, N.; Li, Y.; Du, Q.; et al. Targeting CPT1A-mediated fatty acid oxidation sensitizes nasopharyngeal carcinoma to radiation therapy. Theranostics 2018, 8, 2329-2347. [CrossRef] [PubMed]

142. Deshmukh, A.; Arfuso, F.; Newsholme, P.; Dharmarajan, A. Regulation of Cancer Stem Cell Metabolism by Secreted FrizzledRelated Protein 4 (sFRP4). Cancers 2018, 10, 40. [CrossRef]

143. Sancho, P.; Barneda, D.; Heeschen, C. Hallmarks of cancer stem cell metabolism. Br. J. Cancer 2016, 114, 1305-1312. [CrossRef] [PubMed]

144. Ganapathy-Kanniappan, S.; Geschwind, J.F. Tumor glycolysis as a target for cancer therapy: Progress and prospects. Mol. Cancer 2013, 12, 152. [CrossRef]

145. Zhong, D.; Xiong, L.; Liu, T.; Liu, X.; Liu, X.; Chen, J.; Sun, S.Y.; Khuri, F.R.; Zong, Y.; Zhou, Q.; et al. The glycolytic inhibitor 2-deoxyglucose activates multiple prosurvival pathways through IGF1R. J. Biol. Chem. 2009, 284, 23225-23233. [CrossRef] [PubMed]

146. De Francesco, E.M.; Sotgia, F.; Lisanti, M.P. Cancer stem cells (CSCs): Metabolic strategies for their identification and eradication. Biochem. J. 2018, 475, 1611-1634. [CrossRef] [PubMed]

147. Sun, H.R.; Wang, S.; Yan, S.C.; Zhang, Y.; Nelson, P.J.; Jia, H.L.; Qin, L.X.; Dong, Q.Z. Therapeutic Strategies Targeting Cancer Stem Cells and Their Microenvironment. Front. Oncol. 2019, 9, 1104. [CrossRef]

148. Najafi, M.; Farhood, B.; Mortezaee, K.; Kharazinejad, E.; Majidpoor, J.; Ahadi, R. Hypoxia in solid tumors: A key promoter of cancer stem cell (CSC) resistance. J. Cancer Res. Clin. Oncol. 2020, 146, 19-31. [CrossRef]

149. Bhuria, V.; Xing, J.; Scholta, T.; Bui, K.C.; Nguyen, M.L.T.; Malek, N.P.; Bozko, P.; Plentz, R.R. Hypoxia induced Sonic Hedgehog signaling regulates cancer stemness, epithelial-to-mesenchymal transition and invasion in cholangiocarcinoma. Exp. Cell Res. 2019, 385, 111671. [CrossRef]

150. Chanmee, T.; Ontong, P.; Izumikawa, T.; Higashide, M.; Mochizuki, N.; Chokchaitaweesuk, C.; Khansai, M.; Nakajima, K.; Kakizaki, I.; Kongtawelert, P.; et al. Hyaluronan Production Regulates Metabolic and Cancer Stem-like Properties of Breast Cancer Cells via Hexosamine Biosynthetic Pathway-coupled HIF-1 Signaling. J. Biol. Chem. 2016, 291, 24105-24120. [CrossRef]

151. Bae, K.M.; Dai, Y.; Vieweg, J.; Siemann, D.W. Hypoxia regulates SOX2 expression to promote prostate cancer cell invasion and sphere formation. Am. J. Cancer Res. 2016, 6, 1078-1088.

152. Tang, Y.A.; Chen, Y.F.; Bao, Y.; Mahara, S.; Yatim, S.; Oguz, G.; Lee, P.L.; Feng, M.; Cai, Y.; Tan, E.Y.; et al. Hypoxic tumor microenvironment activates GLI2 via HIF- $1 \alpha$ and TGF- $\beta 2$ to promote chemoresistance in colorectal cancer. Proc. Natl. Acad. Sci. USA 2018, 115, E5990-E5999. [CrossRef]

153. Bai, J.; Chen, W.B.; Zhang, X.Y.; Kang, X.N.; Jin, L.J.; Zhang, H.; Wang, Z.Y. HIF-2 $\alpha$ regulates CD44 to promote cancer stem cell activation in triple-negative breast cancer via PI3K/AKT/mTOR signaling. World J. Stem Cells 2020, 12, 87-99. [CrossRef]

154. Huang, T.X.; Guan, X.Y.; Fu, L. Therapeutic targeting of the crosstalk between cancer-associated fibroblasts and cancer stem cells. Am. J. Cancer Res. 2019, 9, 1889-1904.

155. Li, Y.; Wang, R.; Xiong, S.; Wang, X.; Zhao, Z.; Bai, S.; Wang, Y.; Zhao, Y.; Cheng, B. Cancer-associated fibroblasts promote the stemness of CD24(+) liver cells via paracrine signaling. J. Mol. Med. 2019, 97, 243-255. [CrossRef] [PubMed]

156. López-Gil, J.C.; Martin-Hijano, L.; Hermann, P.C.; Sainz, B., Jr. The CXCL12 Crossroads in Cancer Stem Cells and Their Niche. Cancers 2021, 13, 469. [CrossRef]

157. Cui, C.P.; Wong, C.C.; Kai, A.K.; Ho, D.W.; Lau, E.Y.; Tsui, Y.M.; Chan, L.K.; Cheung, T.T.; Chok, K.S.; Chan, A.C.Y.; et al. SENP1 promotes hypoxia-induced cancer stemness by HIF-1 $\alpha$ deSUMOylation and SENP1/HIF-1 $\alpha$ positive feedback loop. Gut 2017, 66, 2149-2159. [CrossRef] [PubMed]

158. Liu, Y.; Chen, C.; Qian, P.; Lu, X.; Sun, B.; Zhang, X.; Wang, L.; Gao, X.; Li, H.; Chen, Z.; et al. Gd-metallofullerenol nanomaterial as non-toxic breast cancer stem cell-specific inhibitor. Nat. Commun. 2015, 6, 5988. [CrossRef] [PubMed]

159. Su, S.; Chen, J.; Yao, H.; Liu, J.; Yu, S.; Lao, L.; Wang, M.; Luo, M.; Xing, Y.; Chen, F.; et al. CD10(+)GPR77(+) Cancer-Associated Fibroblasts Promote Cancer Formation and Chemoresistance by Sustaining Cancer Stemness. Cell 2018, 172, 841-856.e16. [CrossRef]

160. Beck, B.; Driessens, G.; Goossens, S.; Youssef, K.K.; Kuchnio, A.; Caauwe, A.; Sotiropoulou, P.A.; Loges, S.; Lapouge, G.; Candi, A.; et al. A vascular niche and a VEGF-Nrp1 loop regulate the initiation and stemness of skin tumours. Nature 2011, 478, 399-403. [CrossRef]

161. Su, J.; Wu, S.; Wu, H.; Li, L.; Guo, T. CD44 is functionally crucial for driving lung cancer stem cells metastasis through Wnt/ $\beta$-catenin-FoxM1-Twist signaling. Mol. Carcinog. 2016, 55, 1962-1973. [CrossRef]

162. Chen, R.; Masuo, K.; Yogo, A.; Yokoyama, S.; Sugiyama, A.; Seno, H.; Yoshizawa, A.; Takaishi, S. SNAIL regulates gastric carcinogenesis through CCN3 and NEFL. Carcinogenesis 2021, 42, 190-201. [CrossRef] 
163. Zhang, F.; Liu, B.; Deng, Q.; Sheng, D.; Xu, J.; He, X.; Zhang, L.; Liu, S. UCP1 regulates ALDH-positive breast cancer stem cells through releasing the suppression of Snail on FBP1. Cell Biol. Toxicol. 2021, 37, 277-291. [CrossRef]

164. Vijay, G.V.; Zhao, N.; Den Hollander, P.; Toneff, M.J.; Joseph, R.; Pietila, M.; Taube, J.H.; Sarkar, T.R.; Ramirez-Pena, E.; Werden, S.J.; et al. GSK3 $\beta$ regulates epithelial-mesenchymal transition and cancer stem cell properties in triple-negative breast cancer. Breast Cancer Res. BCR 2019, 21, 37. [CrossRef] [PubMed]

165. Piasecka, D.; Braun, M.; Kordek, R.; Sadej, R.; Romanska, H. MicroRNAs in regulation of triple-negative breast cancer progression. J. Cancer Res. Clin. Oncol. 2018, 144, 1401-1411. [CrossRef] [PubMed]

166. Xu, W.; Ji, J.; Xu, Y.; Liu, Y.; Shi, L.; Liu, Y.; Lu, X.; Zhao, Y.; Luo, F.; Wang, B.; et al. MicroRNA-191, by promoting the EMT and increasing CSC-like properties, is involved in neoplastic and metastatic properties of transformed human bronchial epithelial cells. Mol. Carcinog. 2015, 54 (Suppl. S1), E148-E161. [CrossRef] [PubMed]

167. Sun, Z.; Hu, W.; Xu, J.; Kaufmann, A.M.; Albers, A.E. MicroRNA-34a regulates epithelial-mesenchymal transition and cancer stem cell phenotype of head and neck squamous cell carcinoma in vitro. Int. J. Oncol. 2015, 47, 1339-1350. [CrossRef] [PubMed]

168. Hu, Y.B.; Yan, C.; Mu, L.; Mi, Y.L.; Zhao, H.; Hu, H.; Li, X.L.; Tao, D.D.; Wu, Y.Q.; Gong, J.P.; et al. Exosomal Wnt-induced dedifferentiation of colorectal cancer cells contributes to chemotherapy resistance. Oncogene 2019, 38, 1951-1965. [CrossRef] [PubMed]

169. Lewis, A.C.; Kats, L.M. Non-genetic heterogeneity, altered cell fate and differentiation therapy. EMBO Mol. Med. 2021, 13, e12670. [CrossRef] [PubMed]

170. Azzi, S.; Bruno, S.; Giron-Michel, J.; Clay, D.; Devocelle, A.; Croce, M.; Ferrini, S.; Chouaib, S.; Vazquez, A.; Charpentier, B.; et al. Differentiation therapy: Targeting human renal cancer stem cells with interleukin 15. J. Natl. Cancer Inst. 2011, 103, 1884-1898. [CrossRef] [PubMed]

171. Lee, I.C.; Fadera, S.; Liu, H.L. Strategy of differentiation therapy: Effect of dual-frequency ultrasound on the induction of liver cancer stem-like cells on a HA-based multilayer film system. J. Mater. Chem. B 2019, 7, 5401-5411. [CrossRef] [PubMed]

172. Geng, Y.; Amante, J.J.; Goel, H.L.; Zhang, X.; Walker, M.R.; Luther, D.C.; Mercurio, A.M.; Rotello, V.M. Differentiation of Cancer Stem Cells through Nanoparticle Surface Engineering. ACS Nano 2020, 14, 15276-15285. [CrossRef] [PubMed]

173. Ni, X.; Hu, G.; Cai, X. The success and the challenge of all-trans retinoic acid in the treatment of cancer. Crit. Rev. Food Sci. Nutr. 2019, 59, S71-S80. [CrossRef] [PubMed]

174. Mansour, F.A.; Al-Mazrou, A.; Al-Mohanna, F.; Al-Alwan, M.; Ghebeh, H. PD-L1 is overexpressed on breast cancer stem cells through notch3/mTOR axis. Oncoimmunology 2020, 9, 1729299. [CrossRef]

175. Zhang, B.; Dang, J.; Ba, D.; Wang, C.; Han, J.; Zheng, F. Potential function of CTLA-4 in the tumourigenic capacity of melanoma stem cells. Oncol. Lett. 2018, 16, 6163-6170. [CrossRef]

176. Morrison, B.J.; Steel, J.C.; Morris, J.C. Reduction of MHC-I expression limits T-lymphocyte-mediated killing of Cancer-initiating cells. BMC Cancer 2018, 18, 469. [CrossRef] [PubMed]

177. Liu, J.Q.; Hu, A.; Zhu, J.; Yu, J.; Talebian, F.; Bai, X.F. CD200-CD200R Pathway in the Regulation of Tumor Immune Microenvironment and Immunotherapy. Adv. Exp. Med. Biol. 2020, 1223, 155-165. [PubMed]

178. Tsuchiya, H.; Shiota, G. Immune evasion by cancer stem cells. Regen. Ther. 2021, 17, 20-33. [CrossRef]

179. Lu, L.; Tao, H.; Chang, A.E.; Hu, Y.; Shu, G.; Chen, Q.; Egenti, M.; Owen, J.; Moyer, J.S.; Prince, M.E.; et al. Cancer stem cell vaccine inhibits metastases of primary tumors and induces humoral immune responses against cancer stem cells. Oncoimmunology 2015, 4, e990767. [CrossRef]

180. Guo, M.; Luo, B.; Pan, M.; Li, M.; Zhao, F.; Dou, J. MUC1 plays an essential role in tumor immunity of colorectal cancer stem cell vaccine. Int. Immunopharmacol. 2020, 85, 106631. [CrossRef]

181. El-Ashmawy, N.E.; Salem, M.L.; Khedr, E.G.; El-Zamarany, E.A.; Ibrahim, A.O. Dual-targeted therapeutic strategy combining CSC-DC-based vaccine and cisplatin overcomes chemo-resistance in experimental mice model. Clin. Transl. Oncol. Off. Publ. Fed. Span. Oncol. Soc. Natl. Cancer Inst. Mex. 2020, 22, 1155-1165. [CrossRef]

182. Porter, D.L.; Levine, B.L.; Kalos, M.; Bagg, A.; June, C.H. Chimeric antigen receptor-modified T cells in chronic lymphoid leukemia. N. Engl. J. Med. 2011, 365, 725-733. [CrossRef]

183. Badieyan, Z.S.; Hoseini, S.S. Adverse Effects Associated with Clinical Applications of CAR Engineered T Cells. Arch. Immunol. Ther. Exp. 2018, 66, 283-288. [CrossRef]

184. Wang, Y.; Qi, K.; Cheng, H.; Cao, J.; Shi, M.; Qiao, J.; Yan, Z.; Jing, G.; Pan, B.; Sang, W.; et al. Coagulation Disorders after Chimeric Antigen Receptor T Cell Therapy: Analysis of 100 Patients with Relapsed and Refractory Hematologic Malignancies. Biol. Blood Marrow Transplant. J. Am. Soc. Blood Marrow Transplant. 2020, 26, 865-875. [CrossRef]

185. Raja, J.; Ludwig, J.M.; Gettinger, S.N.; Schalper, K.A.; Kim, H.S. Oncolytic virus immunotherapy: Future prospects for oncology. J. Immunother. Cancer 2018, 6, 140. [CrossRef] [PubMed]

186. Kaufman, H.L.; Kohlhapp, F.J.; Zloza, A. Oncolytic viruses: A new class of immunotherapy drugs. Nat. Rev. Drug Discov. 2015, 14, 642-662. [CrossRef] [PubMed]

187. Chaurasiya, S.; Chen, N.G.; Warner, S.G. Oncolytic Virotherapy versus Cancer Stem Cells: A Review of Approaches and Mechanisms. Cancers 2018, 10, 124. [CrossRef] [PubMed]

188. Chen, P.; Hsu, W.H.; Han, J.; Xia, Y.; DePinho, R.A. Cancer Stemness Meets Immunity: From Mechanism to Therapy. Cell Rep. 2021, 34, 108597. [CrossRef] [PubMed] 
189. Gomez, K.E.; Wu, F.; Keysar, S.B.; Morton, J.J.; Miller, B.; Chimed, T.S.; Le, P.N.; Nieto, C.; Chowdhury, F.N.; Tyagi, A.; et al. Cancer Cell CD44 Mediates Macrophage/Monocyte-Driven Regulation of Head and Neck Cancer Stem Cells. Cancer Res. 2020, 80, 4185-4198. [CrossRef] [PubMed]

190. Peng, D.; Tanikawa, T.; Li, W.; Zhao, L.; Vatan, L.; Szeliga, W.; Wan, S.; Wei, S.; Wang, Y.; Liu, Y.; et al. Myeloid-Derived Suppressor Cells Endow Stem-like Qualities to Breast Cancer Cells through IL6/STAT3 and NO/NOTCH Cross-talk Signaling. Cancer Res. 2016, 76, 3156-3165. [CrossRef]

191. Komura, N.; Mabuchi, S.; Shimura, K.; Yokoi, E.; Kozasa, K.; Kuroda, H.; Takahashi, R.; Sasano, T.; Kawano, M.; Matsumoto, Y.; et al. The role of myeloid-derived suppressor cells in increasing cancer stem-like cells and promoting PD-L1 expression in epithelial ovarian cancer. Cancer Immunol. Immunother. 2020, 69, 2477-2499. [CrossRef] [PubMed]

192. Li, X.; Wang, J.; Wu, W.; Gao, H.; Liu, N.; Zhan, G.; Li, L.; Han, L.; Guo, X. Myeloid-derived suppressor cells promote epithelial ovarian cancer cell stemness by inducing the CSF2/p-STAT3 signalling pathway. FEBS J. 2020, 287, 5218-5235. [CrossRef] [PubMed] 